This manuscript is a EarthArXiv preprint and has been submitted for publication to the AAPG Bulletin, but it has not yet been formally accepted for publication. Subsequent versions of this manuscript may, thus, have slightly different content. When formally accepted, the final version of this manuscript will be available via the 'Peer-reviewed Publication DOI' link on the right-hand side of this webpage. Please feel free to contact any of the authors; we warmly welcome feedback. 


\title{
Analogue modelling of the interplay between gravity gliding and spreading across complex rift topography in the Santos Basin
}

\author{
Leonardo M. Pichel'; Oriol Ferrer²; Christopher A-L. Jackson'; Eduard Roca-Abella ${ }^{2}$ \\ 1 - Basins Research Group (BRG), Department of Earth Science and Engineering, Imperial College \\ London, UK \\ 2 - Institut de Recerca Geomodels, Departament de Ciències de la Terra i de l'Oceà, Universitat de \\ Barcelona, Barcelona, Spain
}

\begin{abstract}
The Santos Basin presents a complex and controversial evolution and distribution of salt tectonics domains. The controversies revolve mainly around the kinematicallylinked Albian Gap and São Paulo Plateau. The Albian Gap is a $\sim 450 \mathrm{~km}$ long and 60 $\mathrm{km}$ wide feature characterized by a post-Albian counter-regional rollover overlying depleted Aptian salt and in which the Albian is absent. The São Paulo Plateau is defined by a pre-salt structural high with significant base-salt topography and overlain by $\sim 2.5 \mathrm{~km}$ thick salt. Another prominent feature is the Merluza Graben, a rift depocentre that underlies the southern portion of the Albian Gap and displays significant (3-4 km) of base-salt relief. Two competing hypotheses have been proposed to explain the origin and kinematics of these provinces. One invokes postAlbian extension within the Albian Gap and contraction in the Sao Paulo Plateau. The other invokes post-Albian salt expulsion in the Albian Gap and salt inflation in the São Paulo Plateau without significant lateral deformation. A recent study shows these processes contribute equally to the evolution of these domains, also demonstrating the importance of the previously neglected base-salt relief. We apply 3D physical modelling to test these new concepts and understand the interplay between laterallyvariable base-salt relief, gliding and spreading on salt tectonics. Our results show a remarkably-similar salt and post-salt evolution and architecture to the Santos Basin as proposed in recent studies. They improve the understanding on the distribution and interaction of salt-related structural styles and gravity-driven processes, being also applicable to other salt-bearing margins.
\end{abstract}


The Santos Basin, located along the South Atlantic Brazilian passive margin, has been centre of scientific debates regarding the timing and kinematics of rifting and breakup, the temporal relationship between salt deposition and rifting, and the evolution of salt tectonic structural styles. The basin presents a complex rifting history, characterized by a rift jump towards Africa that resulted in an ultra-wide Aptian salt basin defined by prominent, rift-related pre-salt topography (Lentini et al., 2010; Garcia et al., 2012;

Davison et al., 2012; Heine et al., 2013; Kukla et al., 2018; Pichel et al., 2021). It is, for that reason, commonly considered the largest and most controversial salt basin in the entire South Atlantic (Lentini et al., 2010; Kukla et al., 2018; Pichel et al., 2021). The main controversies regarding its salt tectonics revolve around the unique structural styles associated with the Albian Gap and São Paulo Plateau, whose origin and kinematics have been discussed for $>30$ years (cf. Demercian et al., 1993; Mohriak et al., 1995; Szatmari et al., 1996; Davison et al., 2012; Quirk et al., 2012; Jackson et al., 2015a,b; Pichel et al., 2018; 2019c).

The Albian Gap is a remarkably large (c. $450 \mathrm{~km}$ long and up to c. $60 \mathrm{~km}$ wide) feature located at the transition between the updip extensional and intermediate translational salt-tectonic domains of the Santos Basin (Fig. 1a-b). It is spatially and genetically associated with an equally large, 6-8 km thick, counter-regional post-Albian saltdetached rollover, and by the near-complete absence of the Albian section above a highly depleted Aptian salt layer (Fig. 1b) (Guerra and Underhill, 2012; Jackson et al., 2015; Pichel and Jackson, 2020b). Two competing hypotheses were originally formulated to describe its genesis and kinematics (see review by Jackson et al., 2015; Pichel and Jackson, 2020): (i) the extensional model, which invokes that the gap and its overlying rollover formed by post-Albian gravity-driven extension accommodated 
by slip on a large counter-regional, listric extensional fault (Demercian et al., 1993;

Cobbold et al., 1995; Mohriak et al., 1995; Guerra and Underhill., 2012; Rowan and Ratcliff, 2012; Quirk et al., 2012); and (ii) the expulsion model, which argues that the Albian Gap was fully established earlier, during the Albian, and that post-Albian deformation was driven by a basinward salt expulsion related to the differential loading of a prograding continental platform without significant lateral extension (Ge et al., Jackson et al., 2015).

Immediately basinward of the Albian Gap, the São Paulo Plateau is characterized by thick (>2.5 km) salt above a large and hydrocarbon-prolific, pre-salt structural high, the Outer High (Gomes et al., 2009; Davison et al., 2012; Fiduk and Rowan, 2012; Jackson et al., 2014; 2015a; Rodriguez et al., 2019). The origin and style of salt-related deformation in the São Paulo Plateau is intrinsically related to the origin and kinematics of Albian Gap, given they are both part of the same gravity-driven system (Jackson et al., 2015b). Thus, extensional models for the Albian Gap imply that the salt and supra-salt post-Albian deformation in the SPP is characterized by translation and regional contraction (Guerra and Underhill, 2012; Fiduk and Rowan, 2012; Quirk et al., 2012; Rowan and Ratliff, 2012). Conversely, in the expulsion-driven model, postAlbian deformation is characterized by salt inflation, but with no significant overburden translation and contraction (Ge et al., 1997; Gemmer et al., 2004; Jackson et al., 2015a,b).

Recent studies, however, demonstrate that salt deformation in the Albian Gap and São Paulo Plateau is three-dimensionally more variable and complex than previously described. For example, Pichel and Jackson (2020b) use an extensive, depthmigrated 2D dataset and balanced structural restorations to demonstrate significant 
51 lateral variability in salt-related structural style within the Albian Gap, and to argue that both post-Albian expulsion and extension played an equally important role on its evolution. This is in accordance with the magnitude of translation $(\sim 30 \mathrm{~km})$ observed in ramp-syncline basins in the adjacent São Paulo Plateau (Pichel et al. 2018; 2019c). Beneath the salt, the underlying basement and basin fill is characterized by a system of horsts and grabens, including the Merluza Graben (MG) (cf. Garcia et al., 2012; Magee et al., 2020) and the Santos Outer High (Fig 1b). The Merluza Graben is partially overlain by the Albian Gap (Fig. 1a), but due to its location and perhaps complexity, it has been relatively understudied in comparison with its adjacent structural provinces. The area is characterized by pronounced (up to $3.5-4 \mathrm{~km}$ ) basesalt relief at its basinward-bounding fault and contains some of the largest diapirs within the entire basin (Pichel et al., 2021). The presence of prominent base-salt relief in the Merluza Graben favours the development of squeezed diapirs, contractional salt anticlines, and ramp-syncline basins, in an area that was previously classified as purely extensional (cf. Mohriak et al., 2008; Davison et al., 2012; Quirk et al., 2012) (Fig. 1a-b). Where the Albian Gap and Merluza Graben overlap, there is also a clear change in the orientation (from NE to $\mathrm{N}$ ) and style of deformation (i.e., fault and rollover polarity) in the Albian Gap as it becomes subparallel to the underlying Merluza Graben in its southern portion (Fig. 1a) (Pichel et al., 2021).

Whilst these recent, largely seismic reflection-based studies have provided advances in the understanding of salt tectonics in the Santos Basin, the kinematic and mechanical plausibility of the arising concepts have not been yet tested with physical or numerical models. In this paper, we use a scaled regional (i.e., representing an area $100 \mathrm{~km}$ long by $60 \mathrm{~km}$ wide) physical model of the Santos Basin to test hypotheses related to its salt tectonic evolution and the way in which rift-related relief controlled 
the subsequent salt-tectonic evolution of the basin. The experiment was designed to test the interplay between: i) rift-related base-salt architecture, ii) gliding and iii) spreading associated with the more controversial structures in the Santos Basin, i.e., the Merluza Graben, the Albian Gap, and the São Paulo Plateau (Fig. 2). It is the first physical modelling experiment to study the linked salt-tectonic evolution of three key, spatially related structural domains: the Merluza Graben, Albian Gap, and São Paulo Plateau. Given that salt-related gliding and spreading over an irregular base-salt surface is common in several other basins (e.g., West Africa, Gulf of Mexico, CamposEspirito Santo), our modelling results also help us understand regional salt tectonics in other salt-bearing rifted margins.

\section{Geological Setting}

The Santos Basin is bound by the Cabo Frio Arch to the northeast and by the Florianopolis Platform to the southwest (Mohriak et al., 1995; Garcia et al., 2012). The basin originated during the Early Cretaceous rift event that ultimately led to the opening of the South Atlantic (e.g., Meisling et al., 2001; Modica and Brush, 2004; Karner and Gambôa, 2007; Mohriak et al., 2008). Rifting was characterized by ESESE extension, which formed NNE-NE-oriented grabens and half-grabens filled by Barremian, syn-rift, fluvial-lacustrine deposits, and that are overlain by an early-tomiddle Aptian, carbonate-dominated sag (i.e., early post-rift) sequence (Meisling et al., 2001; Davison et al., 2012). Regional fault activity decreased during the early Aptian and, by the Late-Aptian, a c. $2.5 \mathrm{~km}$ thick (on average) salt succession had been deposited (Davison et al., 2012; Garcia et al., 2012; Pichel and Jackson, 2020). Salt deposition was controlled by relief inherited from the preceding rift, resulting in spatial variations in original salt thickness and composition (Davison et al., 2012; Garcia et al., 2012; Rodriguez et al. 2018). In pre-salt lows such as the Merluza 
101 Graben and the Deep Marginal Through, salt was up to 3.5-4 km thick (Fig. 1b) (Garcia

102

103

104

105

106

107

108

109

110

111

112

113

114

115

116

117

118

119

120

121

122

123

124

125

et al., 2012; Lebit et al., 2019). Conversely, on pre-salt highs such as the Outer High in the São Paulo Plateau (Fig. 1b), salt was only c. 1-2 km thick (Garcia et al., 2012;

Davison et al., 2012; Rodriguez et al., 2019).

During the early Albian, the Santos Basin became fully marine due to breakup and emplacement of oceanic crust resulting in thermally induced post-rift subsidence (Quirk et al., 2012). During the late Albian, the basin tilted south-eastward, inducing gravity gliding of the salt and its overburden. Salt-related deformation produced numerous thin-skinned, predominantly basinward-dipping, salt-detached normal faults that dismembered the Albian carbonate layer into rafts in the updip extensional domain (zone of extension, Fig. 1) (Demercian et al., 1993; Cobbold et al., 1995; Guerra and Underhill, 2012; Quirk et al., 2012). Post-Albian sedimentation was characterized by margin-scale clastic progradation, with sediments derived from the uplifting of the Serra do Mar Mountain range (Fig. 1a) (Modica \& Brush, 2004). Due to the margin progradation, deformation gradually migrated downdip into the Albian Gap and onto the São Paulo Plateau (Fig. 1) (Quirk et al., 2012; Jackson et al., 2015a, Pichel and Jackson, 2020). Post-Albian salt tectonics was characterized by the basinward expulsion of salt from the Albian Gap, and the development of a hybrid, extensionalexpulsion counter-regional rollover (Pichel and Jackson 2020); this was kinematically balanced by up to c. $30 \mathrm{~km}$ of overburden translation above inflated salt in the São Paulo Plateau (Pichel et al., 2018; 2019c). There, salt deformation was influenced by the rift-related base-salt relief and salt thickness variability in the Outer High, resulting in broadly coeval extension, contraction, and load-driven diapirism, as well as the development of ramp-syncline basins (Pichel et al. 2018; 2019c). The Albian Gap, Merluza Graben, and the Deep Salt Basin were likely also influenced by base-salt 
relief due to the complex rifting and break-up history of the basin (cf. Davison et al. 2012; Garcia et al., 2012; cf. Pichel and Jackson, 2020; Pichel et al; 2021).

\section{Analogue Modelling}

\subsection{Materials}

A well-sorted and rounded dry silica sand (white and coloured) with an average grain size of $200 \mu \mathrm{m}$ was used to simulate brittle rocks of the upper continental crust (presalt and overburden in our natural analogue). It is generally accepted that dry silica sand obeys a Mohr-Coulomb failure criterion at laboratory strain rates (Hubbert, 1951, Horsfield, 1977). The mechanical properties of this sand were measured by Ferrer et al. (2017), who demonstrated an angle of internal friction (ø) of $34.6^{\circ}$, a coefficient of internal friction $(\varphi)$ of 0.69 , a bulk density of $1500 \mathrm{~kg} \cdot \mathrm{m}^{-3}$, and a low apparent cohesive strength of $55 \mathrm{~Pa}$. A transparent, high-viscosity silicone polymer (polydimethylsiloxane or PDMS) was used to model rock salt (referred in the text as "salt" for simplicity). PDMS is a near-Newtonian viscous fluid that, at laboratory strain rates, has a low yield strength, similar to the behaviour of natural salt (e.g., Weijermars and Schmeling, 1986; Dell'Ertole and Schellart, 2013). At room temperature, PDMS has a density of $974 \mathrm{~kg} \cdot \mathrm{m}^{-3}$ and a viscosity of $1.6 \times 10^{-4} \mathrm{~Pa}$.s when deformed at a laboratory strain rate of $1.83 \times 10^{-4} \mathrm{~cm} \cdot \mathrm{s}^{-1}$ (Dell'Ertole and Schellart, 2013). Table 1 summarizes the scaling parameters of the experiments as well as the mechanical properties of the modelling materials.

\subsection{Experimental Setup}


Our model simulates the salt tectonics evolution of the proximal portion of the southern

Santos Basin, comprising its updip salt pinch-out and three main structural provinces: the pre-salt Merluza Graben, and the post-salt Albian Gap and São Paulo Plateau (Figs. 3-4). This corresponds to a three-dimensionally variable setting, in which the pre-salt relief related to the Merluza Graben and adjacent base-salt steps vary alongstrike in steepness and orientation, resulting in differences in salt basin geometry and salt thickness (Figs 4-6). This produces along-strike and temporal variations in gravity-

driven gliding and spreading, resulting in complex and multiphase salt tectonics (Figs. 5 and 6). We thus divide the model into a northern and southern domain, in which the base-salt structures are oriented orthogonal and oblique, respectively, to the main direction of gravity-driven tectonic transport.

Physical modelling was undertaken at the Geomodels Analogue Modeling Laboratory (Universitat de Barcelona) in a deformation rig that was $120 \mathrm{~cm}$ long and $70 \mathrm{~cm}$ wide (Fig. 4a). Two fixed lateral glass walls and two metal plates confined the analogue materials during the model run. Dry silica sand was used to build the sub-salt topography, and a mixture of silica sand and clay was used locally to sculpt a steeper dip for the sub-salt faults. We modelled two major landward-dipping, sub-salt faults that display a variable orientation along strike (from orthogonal to oblique to the tectonic transport) (Fig. 4a). The baseplate was tilted $4^{\circ}$ and the polymer was emplaced above the pre-salt topography. After 48 hours, when the polymer had settled, a $5 \mathrm{~mm}$-thick, pre-kinematic layer of blue sand was manually poured above the entire model and levelled with a scraper (Fig. 4b). Deformation was triggered by tilting of the baseplate a further $2^{\circ}$ basinward (driving gravity gliding) and by adding a wedge of $4 \mathrm{~mm}$ thick blue sand (driving gravity spreading) (Fig. 4c). 
Syn-kinematic prograding wedges of white and coloured (red and yellow) dry silica sand were poured onto the experiment and then levelled every 2 hours. Prior to the deposition of each syn-kinematic wedge, the baseboard was tilted back $2^{\circ}$. The regional datum was progressively raised $1 \mathrm{~mm}$ before the deposition of each sand wedge. The roof of the main salt structures elevated above the regional datum during the experiment were vacuumed to simulate erosion. After the deposition of each synkinematic wedge, the baseboard was again tilted $2^{\circ}$ basinward to restart gravitational gliding. A trench of sand and polymer was gradually removed at the basinward metal plate to create an open-toe system. At the end of the model run, we covered the experiment with a fine-grained, post-kinematic, dry silica sand to preserve the final topography and inhibit further polymer flow. Finally, we section the model into 2003 mm-thick vertical slices.

\subsection{Model Analysis}

Computer-controlled high-resolution digital cameras took overhead and oblique, timelapsed photographs during the experiment to document the model kinematics. In addition, we also took photographs of specific structures to aid our analysis of the model results. We used overhead time-lapse photographs and digital image correlation (DIC) to quantify particle displacements and strain (Adam et al., 2005). The final sections of the model were also documented by high-resolution photographs to analyse the along-strike variability of the structures.

\section{Results}

We first show the map-view evolution of the model using overhead time-lapse photography (Figs. 5 and 6) with DIC data (Figs 7 and 8). We then describe multiple 
cross-sections throughout different domains of the model and then compare them with natural examples from the Santos Basin, Brazil.

\subsection{Overhead evolution}

The earliest stages of the model evolution correspond to deposition of the first two sedimentary wedges simulating Albian strata and initial seaward tilting of the model (Fig. 4c and 5a-b). During the first stage, deformation is focussed updip and within the large half-graben that, in our model, reflects the Merluza Graben (Fig. 5a, 7a and 8a). Broadly symmetric and linear grabens, cored by reactive diapirs and salt rollers, form updip of the half-graben, whereas a wide zone of inflated salt and relatively gentle overburden folding forms within it (Fig. 5a and 8a). This zone of inflation follows the sub-salt trend, thus being wider and oblique to gravity-driven transport in the south. Minor, short-wavelength buckle-folds form further downdip of the half-graben, above the adjacent sub-salt plateau (Fig. 5a and 8a).

Earlier-formed structures are amplified during deposition of the second sedimentary wedge, which represents Upper Albian strata (Figs. 4c and 5b). Updip extension is preferentially accommodated along basinward-dipping normal faults, with salt reaching the surface at the core of early-formed grabens, forming linear reactivepassive salt walls. The ongoing basinward evacuation and inflation of salt above the Merluza Graben results in amplification of the previous structures, i.e., salt plateau and gentle overburden folds further downdip (Fig. 5b). To the north, where the halfgraben is narrower $(30 \mathrm{~cm})$, there is greater inflation and overburden uplift than in the south where: (i) the graben is wider; and (ii) its associated base-salt step trends oblique rather than normal to the overall direction of salt and overburden translation (Figs. 4a and 5b). During this stage, overburden erosion results in development of a 
25-30 cm wide salt diapir that reaches the model surface in the north of graben (Fig. 5b). Further downdip, over the sub-salt plateau (equivalent to the São Paulo Plateau of Santos), there is widespread salt inflation and overburden buckle-folding (Fig. 5b).

In the next stage, equivalent to earliest post-Albian times, continued progradation results in additional updip extension and ongoing basinward translation of post-salt structures, with new normal faults and extensional turtle anticlines developing updip of the large half-graben (Fig. 5c). Some of the previous reactive-passive walls are buried, while new ones form slightly further downdip, but still within the graben (Fig. 5c). In the north domain, the wide $(\sim 22 \mathrm{~cm})$ diapir inflates further and starts to translate basinward, beyond the fault bounding the sub-salt half-graben (Fig. 5c, 7b and 8b). The updip portion of the wide diapir, located above the sub-salt graben, is further uplifted, and bound by an expulsion rollover that extend throughout the entire length of the model (Figs. 5c and 8b). Further downdip, over the sub-salt plateau, new saltcored buckle folds form while earlier-formed folds are tightened (Fig. 5c and 8b).

In the next stage, as the margin progrades, the most proximal salt structures, updip of the half-graben, become dormant as salt is expelled downdip. Further basinward, within the sub-salt structural low representing the Merluza Graben, extension continues, as does the related growth of reactive and passive diapirs (Fig. $5 d$ ). The post-Albian sediments and associated expulsion rollover reach the landward-dipping sub-salt fault, filling the associated half-graben, whilst expelling most of its salt basinward (Fig. 5d). Consequently, the wide diapir formed during the second stage inflates and widens further (to $\sim 34 \mathrm{~cm}$ ) and, in the northern part of the model, translating nearly completely beyond the sub-salt fault (Fig. 5d). To the south, where the inflated salt remained largely covered by Albian-equivalent strata, reactive and 
passive diapirs form in response to overburden extension and dismembering of their roof (Fig. 5d).

244 In the following stage (Figs. 6a, 7c and 8c), as sediments prograde beyond the subsalt half-graben and reach the sub-salt plateau, there is little deformation updip of the graben. Extension migrates basinward and is primarily accommodated by counterregional (i.e., landward-dipping) normal faults at the updip portion of the half-graben (Figs. 6a and 8c). The expulsion rollover formed at the updip edge of the wide diapir is faulted and associated with counter-regional normal faults (Fig. 6a and 8c). The diapir widens (reaching up to $\sim 38 \mathrm{~cm}$ ) and translates further basinward, merging laterally with passive salt walls to the south. It partially encases Albian folds at its seaward end whilst developing new folds above its seaward end (Fig. 6a and 8c). The reactive diapirs formed above the inflated salt in the south are squeezed as they approach the downdip base-salt step (Fig. 6a and 8c).

The next stage is similar to the preceding one, being characterised by continuous progradation and basinward migration of extension (Fig. 6b, $7 d$ and $8 d$ ). This results in amplification and advance of counter-regional faults and the downdip expulsion rollover as well as complete burial of the most proximal structures (Fig. 6b). The wide salt diapir continues to advance basinward and expand laterally by coalescence with passive salt walls in the south, reaching up to $\sim 40 \mathrm{~cm}$ of width, while a new foldbelt forms in between them where the salt remains covered by the Albian (Fig. 6b and 8d). Significant along-diapir variability is observed at this stage, i.e., the wide diapir is shortened in the south where it is partially covered, whilst it widens to the north where it reaches the model's surface and can translate faster (Fig. 6b, $7 d$ and $8 d$ ). The distal 
foldbelt is tightened as salt flow is partially buttressed over base-salt steps and by the gradually basinward-thinning salt over the sub-salt plateau (Fig. 6b, 7d and 8d).

In the next, the structures within the half-graben become largely dormant due to continuous basinward salt evacuation and overburden translation onto the sub-salt plateau (Fig. 6c). Updip deformation in the northern portion of the half-graben is characterized by development of counter-regional normal faults and basinwarddipping extensional rollovers and/or turtle anticlines, most of which associated with crestal collapse grabens (Fig. 6c). In contrast, southern portion of the half-graben contains $10-20 \mathrm{~cm}$ long, reactive-passive walls that are bound by large, counterregional faults formed during the previous stage (Fig. 6b-c). The expulsion rollover also becomes bound by a large counter-regional normal fault at its basinward edge and is thus classified as a hybrid rollover formed by a combination of salt expulsion and overburden extension (Fig. 6b-c) (see Pichel and Jackson, 2020). The adjacent salt diapir now starts to narrow (down to $\sim 30 \mathrm{~cm}$ ) while still translating seaward (Fig. $6 c)$.

At the last stage, progradation results in complete burial of all salt structures updip and within the half-graben and nearly complete burial of structures in the updip portion of plateau (Fig. 6d).

\subsection{Cross-Sectional Architecture and 3D variability}

This multiphase and complex structural evolution described above is also recorded by the cross-sectional geometry of salt and post-salt structures (Figs. 9-11). Due to the 
lateral variability of the base-salt relief in our model, we present and describe regional (Fig. 9) and detailed cross-sections for both its southern (Fig. 10) and northern (Fig. 11) domains of the 1) Merluza Graben and 2) Albian Gap and São Paulo Plateau.

\subsubsection{Merluza Graben}

The cross-sections demonstrate a transition from predominantly extensional deformation at the updip portion of the sub-salt half-graben, equivalent to the Merluza Graben, to a more complex, multiphase deformation against its bounding landwarddipping fault, equivalent to the Merluza Fault (Figs. 9-11). In the northern and southern domains, updip extension is associated with development of listric normal faults, which are dominantly basinward-dipping updip of the half-graben and landward-dipping within the graben itself. These faults are cored by asymmetric and/or triangular diapirs defined as salt rollers and overlain by extensional rollovers and/or turtle anticlines (Figs. 9-11). The post-salt strata analogous to the Albian succession form a series of dismembered rafts spaced 2-6 cm (blue in Fig. 1b, 9-11). Flip-flop rollers (cf. Quirk et al., 2012) and diapir-fall geometries are also observed within and updip of the Merluza Graben (Figs. 9, 10 and 11b).

Structures developed within the structural low equivalent to the Merluza Graben are more variable. They present upturned and thinned, near-diapir strata (axial-traces in dashed black lines, figs. 9-11) indicating an early phase of salt expulsion and loaddriven diapirism. This is followed by late extension and diapir collapse, expressed by the development of large, landward-dipping normal faults and hybrid rollovers (HR) (Fig. 9a, 10 and 11a). These structures also present small, c. $1 \mathrm{~cm}$ salt wings on their flanks and/or inflated diapir bulbs, suggesting a degree of shortening and minor salt extrusion prior to extension. Further downdip, above the sub-salt fault representing the 
312 Merluza Fault, there is significant along-strike structural variability. To the north, there is upturned and thinned Albian strata adjacent to (dashed black lines, fig. 9a and 11a) or above (Fig. 9b) the Merluza Fault, whereas in the south the Albian forms broadly tabular rafts that typically terminate $5-8 \mathrm{~cm}$ updip of the fault (Fig. 10 and 11b). Diapirs overlying or just downdip of the sub-salt fault display complex cross-sectional geometries, being defined by $2-3 \mathrm{~cm}$ wide, landward-verging salt tongues that are near-parallel to the post-Albian strata (Figs. 9-11). The geometry of post-Albian strata above the Merluza Fault can vary from near-diapir upturn (Figs. 9a-b, 10a and 11a), to large expulsion rollovers above depleted salt or adjacent to large diapirs (Fig. 9a, 10 and 11).

\subsubsection{Albian Gap and São Paulo Plateau}

The area immediately downdip of the (modelled) Merluza Graben corresponds to a 25 $\mathrm{cm}$ wide, sub-salt high that is characterized by the complete absence of blue sand (i.e., equivalent to Albian strata). This gap, which we interpret as equivalent to the Albian Gap (cf., Mohriak et al., 1995; Jackson et al., 2015), extends further landward onto the Merluza Graben and basinward onto the São Paulo Plateau, varying in width from $30-40 \mathrm{~cm}$ in the southern domain to $40-50 \mathrm{~cm}$ in the northern domain (Figs. 911). The structure is characterized by welded to depleted salt that is overlain by postAlbian rollovers and turtle anticlines (Figs 9-11). It also contains less prominent, postAlbian, bowl-shaped minibasins with near-diapir upturned strata in its most distal portions (Fig. 11).

The overhead views described earlier show that the rollovers (HR) and turtle anticlines are formed by a combination of overburden extension and load-driven salt expulsion into adjacent diapirs (Figs 9-11). These two processes and their resultant structures 
are spatially and temporally related, occurring in different times and in different places as the post-Albian equivalent sediments prograde. Extension is accommodated by the formation of basinward-dipping listric normal faults $(r e d)$ at the flank of and above diapirs at the updip portion of the Albian Gap, on the footwall of the Merluza Fault (Fig. 10 and 11a). Load-driven salt expulsion and diapirism are record by either sigmoidal, rollover-style stratal geometries that are associated with sediment wedges that thicken basinward, before thinning and upturning against large (3-4 cm tall and 5-6 cm wide) diapirs to form halokinetic sequences (cf., Giles and Rowan, 2012) (Figs. 9-11). The diapirs associated with overburden extension are asymmetric, triangular, and are thus typical of rollers, whereas the ones associated with load-driven processes present broader and sinusoidal geometries (Figs. 9-10). In the northern domain, where the Albian Gap is wider, the post-Albian diapir geometries are more variable and present more evidence for faulting and extension (Fig. 9 and 11a). In the southern domain, there is little visible extension and less significant turtle geometries, although the diapirs are more frequent and generally larger (c. $1 \mathrm{~cm}$ taller and 3-5 cm wider, Figs. 10 and $11 a)$.

Further basinward, over the next base-salt high defining the São Paulo Plateau, there are broad (c. 4-10 cm wide) diapirs that pass basinward onto salt-cored buckle-folds minibasins. The buckle-folds comprise broadly tabular and folded Albian strata that are overlain by thin $(<1 \mathrm{~cm})$ post-Albian growth strata. (Fig. 11). These structures are formed as salt is expelled basinward from underneath the Albian Gap and inflates and shortens by buttressing of salt flow against landward-dipping base-salt steps and the toe of the model. 


\section{Discussion}

\subsection{Understanding salt tectonic processes in the Santos Basin}

Our experiment simulated three-dimensionally variable salt flow and overburden deformation across a complex framework of base-salt structures; by doing this, our model explored the origin and evolution of salt-tectonics structures imaged in seismic reflection data in the southern Santos Basin, offshore Brazil (Figs. 2-4). The base-salt geometry in the model reproduces the observed regional structural framework (Figs. 3-4) (cf. Rodriguez et al., 2019; Pichel et al., 2019c; 2021), which is defined by a regionally basinward-dipping base-salt, and a large proximal half-graben (the Merluza Graben) that passes downdip onto a set of landward-dipping base-salt steps that form the edge of the São Paulo Plateau (Figs 3-4 and 9-11). Our model also reproduces the main structural styles and related kinematics inferred from recent studies (Pichel et al. 2019b-c; 2021; Pichel and Jackson, 2020b). These processes are post-salt gravity-driven gliding and spreading over three-dimensionally variable base-salt topography. Our experiments are thus suitable to test these recent hypotheses and understand what controls the structural evolution and salt tectonics in the area.

At the largest, regional scale, our model replicates the main salt and overburden structures (Figs. 11 and 12), which display similar distribution, orientation, dimension, and kinematics to the study-area (Figs. 3 and 12-13). For example, salt rollers, bounded by either basinward- or landward listric faults and extensional rollovers occur in the updip portion of the Merluza Graben, whereas complex and variable styles of diapirism form adjacent to the Merluza Fault. There, deformation is characterized by early (i.e., Albian to early post-Albian) salt inflation and passive diapirism, followed by salt expulsion and overburden extension, the latter being accommodated by the development of counter-regional normal faults (Figs. 5-13). Some of these diapirs 
show evidence of squeezing (Figs. 8-9 and 13a), occasionally displaying small salt tongues like those observed near the Merluza Fault (Fig. 11b). Post-Albian rollovers and turtle anticlines form adjacent to and downdip of the Merluza Fault, directly overlying depleted salt (i.e., Albian strata are absent; Figs. 7-13). The Albian gap in the model presents nearly-identical scaled dimensions, geometry, orientation and relationship to the underlying pre-salt framework to the Albian Gap in nature (Figs 1213). The post-Albian contains turtle anticlines and hybrid rollovers, within which strata are upturned next to bounding diapirs, or that thin or thicken basinward against listric normal faults (Figs. 6-13). In the São Paulo Plateau, there is salt inflation as salt is 
basinward dip of the base-salt within the graben at the time of salt deposition. This

412 would promote less gliding and diapirism in its updip portion and could explain, at least partially, these discrepancies. In addition, the reactivation of sub-salt faults by thickskinned extension would likely promote less salt extrusion within and basinward of the half-graben and, consequently, halt the development of complex diapir geometries. It would also favour more salt flowing towards and being trapped against its main fault, explaining why in our models, where the salt layer is not disrupted, the salt deposited over the modelled Merluza Fault is able to flow basinward of this structure.

We also observe in our models the presence of Albian-equivalent strata encased within the salt, above the distal sub-salt plateau (Fig. 6a-b). These features form due to basinward advance of the near-surface salt walls over the previously folded prekinematic post-salt strata (Fig. 6a-b). Although such structures have not yet been described from the Santos Basin, they have been observed in other salt basins (e.g., Precaspian, Fernandez et al., 2017) and other physical models (Brun and Fort, 2011). These structures could have formed as a limitation of our modelling approach associated with the lack of pelagic-type sedimentation in the deep-basin, i.e., this could have impeded basinward translation of the salt plateau and consequent encasement of the folded post-salt strata. However, it is also possible that these features do occur in the Santos Basin but have not been yet properly imaged or drilled. The presence of seismically reflective, disrupted, and folded strata within some salt walls in the São Paulo Plateau (Fig. 12), like the ones observed in our models (Figs. 9-11), may support this hypothesis.

5.2. The interplay between three-dimensionally variable base-salt relief, gliding and spreading 
435 Our 3D physical experiments capture the complex evolution of gravity-driven salt tectonics in response to the interplay between gliding, spreading, and laterally variable base-salt relief. Our work expands on the recent advances in our understanding of the dynamics of salt flow over base-salt relief (cf., Dooley et al., 2016; 2018; Ferrer et al., 2017; Pichel et al., 2019b) by: (i) simulating salt flow over more variable base-salt geometries then previously considered; and (ii) by exploring the interplay between a prograding sediment loading (i.e., spreading) with gravity gliding (Fig. 14).

In our experiments, the landward-dipping normal faults produce half-grabens and semi-isolated salt sub-basins that promote strong partition of salt flow and overburden translation. Salt flows basinward along regionally basinward-dipping base-salt and/or basinward-dipping hangingwalls before it is buttressed against landward-dipping faults (Fig. 14). This generates extension with development of fault-bounded salt rollers, extensional turtles and/or rollovers, and downdip salt inflation and shortening over their bounding fault and/or footwall crests (Figs. 5-11 and 14a-b). This style of structural partition has been observed in previous physical analogue models (cf., Dooley et al., 2016, 2018; Pichel et al., 2019b).

Our experiment shows that differential loading can enhance or reduce the effects of salt flux variations driven by gliding over base-salt topography (Fig. 14c), thus influencing the spatial and temporal distribution of salt structures (Fig. 14b-c). For example, differential loading over basinward-dipping hangingwalls can amplify top-salt subsidence and salt inflation at their base or against their bounding landward-dipping faults. This favours the development of diapirs and associated minibasins or expulsion rollovers that are larger than in a pure gliding scenario (Fig. 14a-b). This is observed over the Merluza Fault in the Santos Basin (Fig. 13) and the equivalent structure in our experiment (Figs. 5-11). 
460 Conversely, salt expulsion from underneath prograding sediments may promote transient salt inflation and overburden shortening above basinward-dipping hangingwalls, where extension would be expected if deformation was driven purely by gliding. This is the case when basinward-dipping base-salt segments lie immediately basinward of the prograding wedge/slope (Figs. 5 and 14b). This is observed in our model where early salt inflation and contraction (i.e., buckle-folding) occurred ahead of the progradation front and above the basinward-dipping footwall of the largest presalt fault, i.e., Merluza Fault (Figs. 5, 8a-b, 14a-b). As the sediment wedge progrades and the locus of maximum load shifts basinward, beyond the fault, the initially inflated salt and contractional domain extend (Figs. 6, 8c-d, 14c). This is observed, in both model and natural examples, by the relatively late development of fault-bounded salt rollers, extensional and/or hybrid (extension-expulsion) rollovers and turtle anticlines above previously inflated salt in the footwall of the Merluza Fault (Figs. 6-13).

The timing, geometry and distribution of the salt structures is also influenced by the orientation (i.e., obliquity) of sub-salt faults and related half-grabens relative to the direction of tectonic transport, which in turn controls also the steepness and height of base-salt steps (Figs. 9-11). Consequently, the orientation and dimension of salt and overburden structures change between the northern and southern domains of our model (Figs. 5-6) and in nature (Fig. 3), as they tend to follow the trend of the basesalt topography. These are perpendicular to the direction of tectonic transport in the northern domain and oblique in the southern domain (Figs. 3 and 5-6). In the northern domain, the largest pre-salt graben is narrower and orthogonal to the tectonic transport, promoting greater salt inflation and overburden uplift, which is aided by (simulated) erosion, and that promotes earlier (i.e., Albian) development of a large diapir (Fig. 5a-b). In the south domain, the wider and oblique pre-salt graben produces 
an equally wide, inflated salt structure. In both domains, the inflated salt has a broadly similar planform to the underlying graben (Fig. 5). Because of its greater width and the obliquity of base-salt relief, salt inflation and overburden uplift are less and over a wider salt bounding fault, thus becoming gradually wider than laterally equivalent salt structures in the south (Figs. 5-6).

These lateral variations of salt flow produce gradients of salt thickness/supply and overburden thickness throughout the remaining model evolution that result in contrasting styles, kinematics, and dimension of salt structures between the northern and southern domains (Figs. 5-9). In the north, the greater salt and overburden translation resulted in greater occurrence of fault-bounded salt rollers and basinwarddipping normal faults, as most of the salt flowed downdip of the footwall of the Merluza the Merluza Fault. Consequently, more salt remained there towards the end of the model, producing taller and more symmetric, load-driven diapirs and minibasins, and meaning less seaward salt inflation above the base-salt plateau than in the northern domain (Figs. 6-11). This spatial and temporal variability of salt deformation are also observed by variations in flow vectors in overhead DIC images (Fig. 7). Where basesalt structures are oblique to transport, there is generally a change in the direction and magnitude of salt flow. For example, in the early stage of model evolution, there is divergent salt flow where the Merluza Fault is oblique to the transport direction with salt flow also becoming oblique and near-parallel to the sub-salt fault (Fig. 7a). At the early stages of model evolution, the magnitude of lateral salt flow is also greater in the 
south, within the oblique portion of the Merluza Graben where the landward-dipping base-salt step is gentler and smaller (Fig. 7a-b). Conversely, vertical salt flow and inflation are greater in the north where the sub-salt graben and its bounding fault are orthogonal to the transport direction (Fig. 7a-b). These earlier patterns, however, change at later stages as salt breaks through the cover to form passive diapirs that accommodate greater lateral salt flow than areas covered by sediments (Figs. $7 b-d)$. This is seen at intermediate model stages (Figs. 6 and 7b-c), as lateral salt flow is greater in the north, along the wide diapir formed above the orthogonal segment of the Merluza Fault.

\subsection{Gravity-driven fault polarity and rollover kinematics}

Another important feature observed in our model is the spatial and temporal variability between normal fault polarity, extension-, and expulsion-related processes, and their resulting depocenter (i.e., rollover, minibasins and turtles) geometries (Figs. 9-11). For each basinward-dipping base-salt segment, there is commonly a transition between proximal and/or earlier basinward-dipping faults transitioning downdip, and through time, into landward-dipping faults (Fig. 9). This suggests that basinward-dipping normal faults tend to form earlier when the overburden is thinner and thus, primarily by gliding, whereas landward-dipping (i.e., counter-regional) faults form later when differential loading (i.e., spreading) becomes more dominant. Whereas basinwarddipping normal faults are readily associated with extensional rollover geometries, the landward-dipping faults have also more variable growth strata (i.e., rollover and/or upturned halokinetic-sequences) throughout their width and height (Figs. 9-11)

532 Extension rollovers are characterized by stratal thickening and downturn towards normal faults (cf. Jackson and Hudec, 2017). Expulsion rollovers present sigmoidal 
534 growth strata ${ }_{2}$ with seaward thickening followed by thinning and upturn against their bounding structure that can be a salt diapir or anticline, and/or normal faults (cf., Jackson and Hudec, 2017; Pichel and Jackson, 2020b). These are end-member geometries and structures; it is more likely a combination and/or alternation of these two processes occur in nature. We, thus follow the terminology of Pichel and Jackson (2020b) and use extension- and expulsion-dominated rollovers and, in the case where both processes have a similar contribution, hybrid-rollovers. In our model, extensiondominated rollovers and related turtles are observed almost exclusively in the most proximal part of the model, updip and above the hangingwall of the Merluza Fault, where the base-salt dips basinward and where salt was originally thinner (Figs. 9-11). Further seaward, adjacent to and beyond the Merluza Fault, there are expulsiondominated rollovers (ER) that are characterized by basinward-dipping, sigmoidal growth strata that are locally upturned against inflated salt diapirs (Figs 9-11). They occur above either basinward-dipping (Fig. 9a and 10a) and landward-dipping basesalt (Fig. 10b and 11a) and form in areas of previously inflated salt (Figs. 5-6). Intermediate, hybrid rollovers (HR) also occur in between those two, updip of the Merluza Fault (Figs. 10-11a).

Our model simulates three-dimensionally variable salt flow, diapirism and overburden deformation driven by the interplay between laterally variable base-salt relief, gravitygliding and spreading. The model tests the more recent hypotheses (cf., Pichel and Jackson, 2020; Pichel et al., 2021) for the kinematics of salt tectonics in a highly controversial province in the Santos Basin by reproducing the spatial and temporal distribution of the salt tectonic processes and boundary conditions inferred by these authors. The model produces a remarkably similar evolution and architecture of salt 
and post-salt deformation to the study-area, thus validating the main arguments proposed in these recent studies and ultimately helping to solve the long-lived debate of salt tectonics in the Santos Basin.

The results afford an improved understanding on the interaction and distribution of salt-related gravity-driven processes (i.e., gliding, spreading, and salt flux variations over base-salt relief) and their associated structural domains. They illustrate the primary controls on the genesis and 3D variability of depocentres (i.e., extension- vs expulsion-dominated rollovers, turtle anticlines vs minibasins), normal faults (i.e., counter-regional vs regional faults) and salt structures (i.e., reactive vs passive diapirs). They also shed light on the lateral variability of salt and overburden translation as a consequence of dynamic salt supply and base-salt relief. Thus, despite their focus in simulating salt tectonics in the Santos Basin, the structural processes and saltrelated geometries modelled are also comparable and relevant to many other saltbearing rifted margins (e.g., Gulf of Mexico, West Africa and other parts of Brazil).

As with all models, this one also presents obvious limitations. There are other parameters that despite having only local or second-order importance in the studyarea and, thus are not included in this model, may be important in other salt basins. For example, our model does not include reactivation of pre-salt normal faults coeval 577 to gravity-driven salt tectonics. This is likely to have occurred in portions of the 578 Campos-Santos basins (cf., Davison et al., 2012; Pichel et al., 2021) as well as other salt-bearing rifted margins, such as northern Gulf of Mexico, West Africa, and the North, Red and Barents seas. These locations are also characterised by different riftrelated base-salt geometries (i.e., half-grabens with different fault polarities) that despite not being as important in the study-area as the ones modelled, are relevant for other parts of Santos (e.g., seaward of the São Paulo Plateau) and other salt 
584 basins. These and other parameters such as different post-salt sedimentation styles 585 and rates are worthy testing in the future using physical and/or numerical modelling 586 studies.

\section{Acknowledgements}

588 We would like to thank Imperial College London for awarding the Arthur Holmes 589 Centenary Grant which covered all travelling expenses of the first author to work for 1 590 month at the Geomodels Analogue Modeling Laboratory, Universitat de Barcelona. 591 We thank Frank Peel for the insightful discussions about tectonics in the Santos Basin.

592 We also thank Oscar Gratacos and Marco Snidero for helping to flip the enormous 593 model used in this study. 
(a)
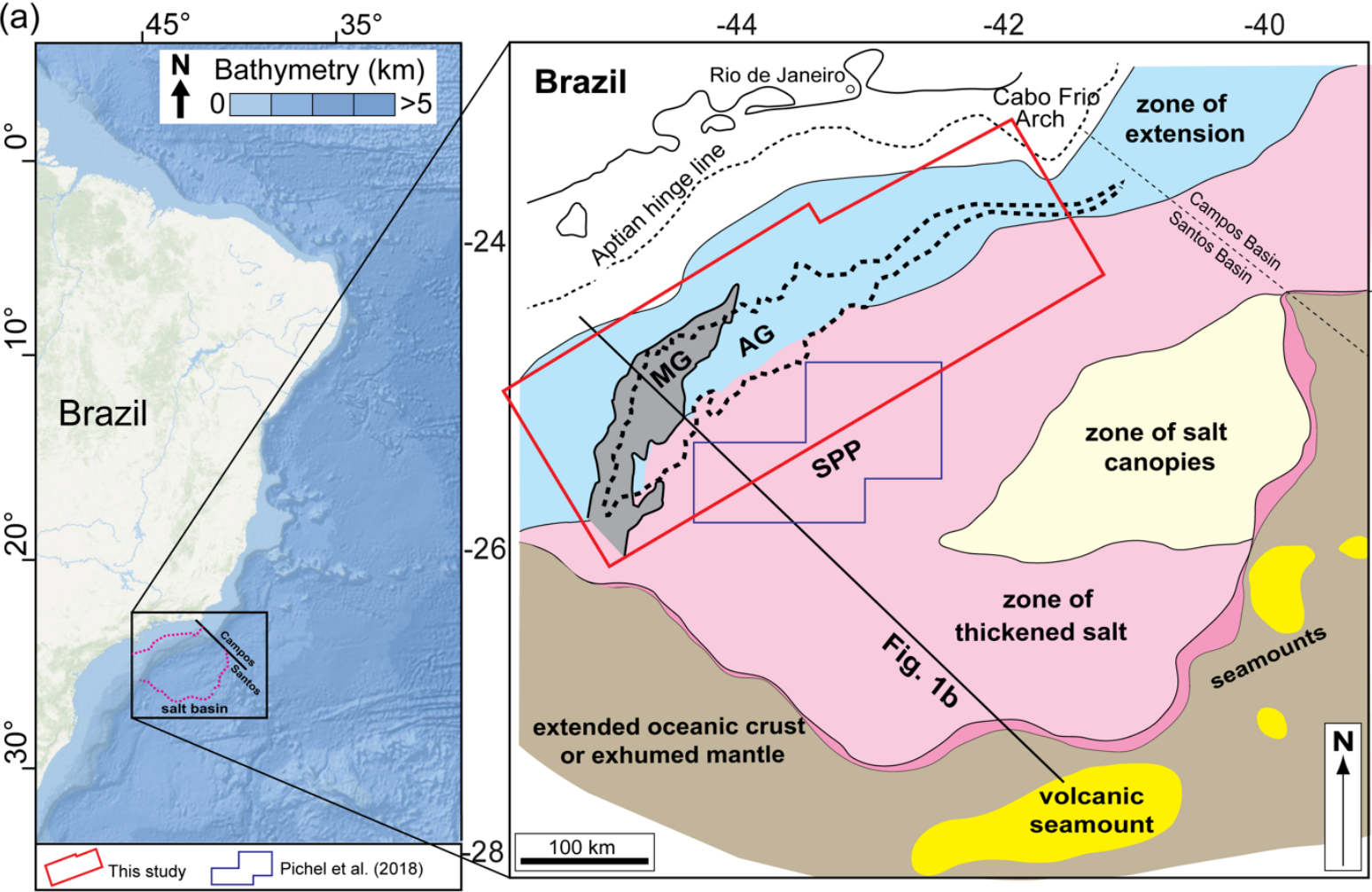

(b)

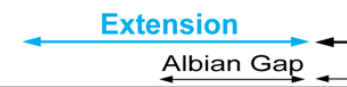

Translation

Contraction

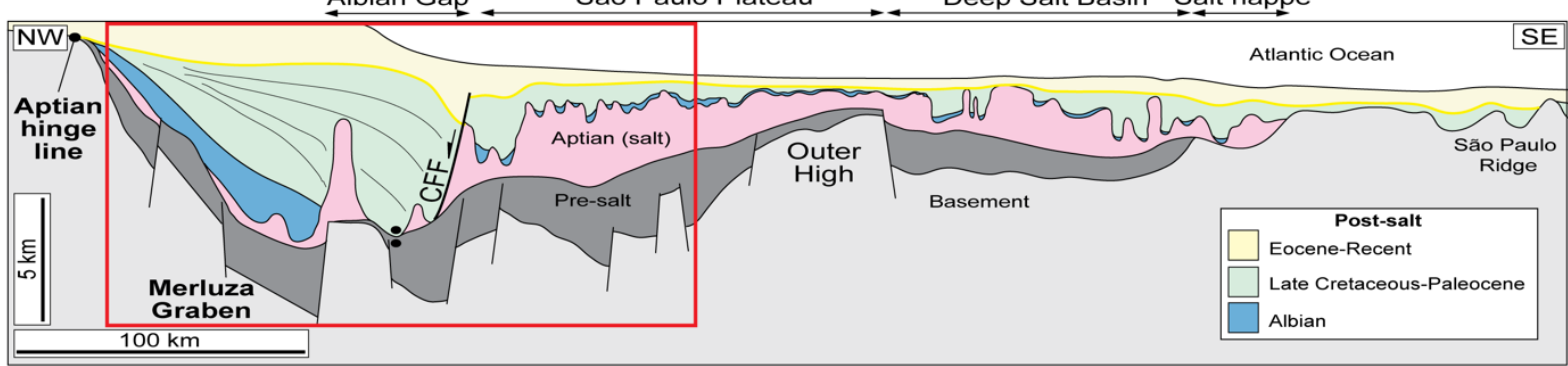

Figure 1: (a) Bathymetry and structural maps showing the salt-related structural domains offshore SE

Brazil including the outline of the Merluza Graben and Albian Gap, focus of the study, and seismic datasets utilized in previous studies from Jackson et al., 2015; Pichel et al., 2019c, 2021 (adapted from

Davison et al., 2012; Pichel and Jackson 2020b). (b) Regional geoseismic cross-section showing the main regional salt-related structural domains offshore the Santos Basin and the area modelled in our physical experiment in red polygon (adapted from Jackson et al. 2015b). CFF refers to the Cabo Frio Fault bounding the Albian Gap. 
(a) Previous Models (Dooley et al., 2018)

- gliding over symmetric horst-graben pairs

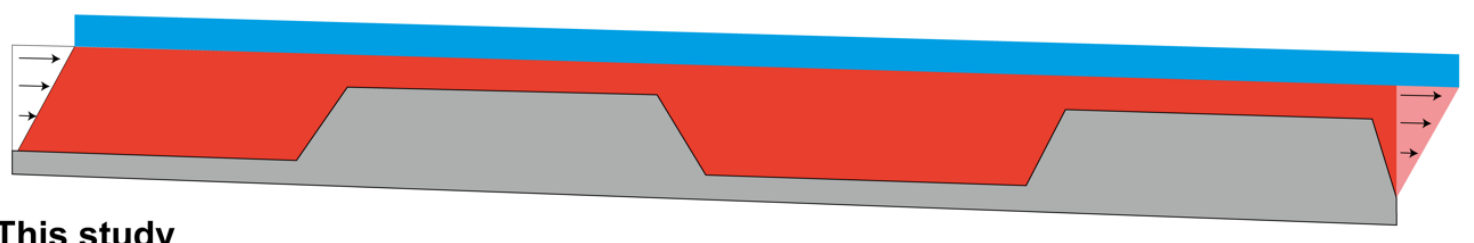

(b) This study

- gliding + spreading over assymmetric and 3D-variable pre-salt

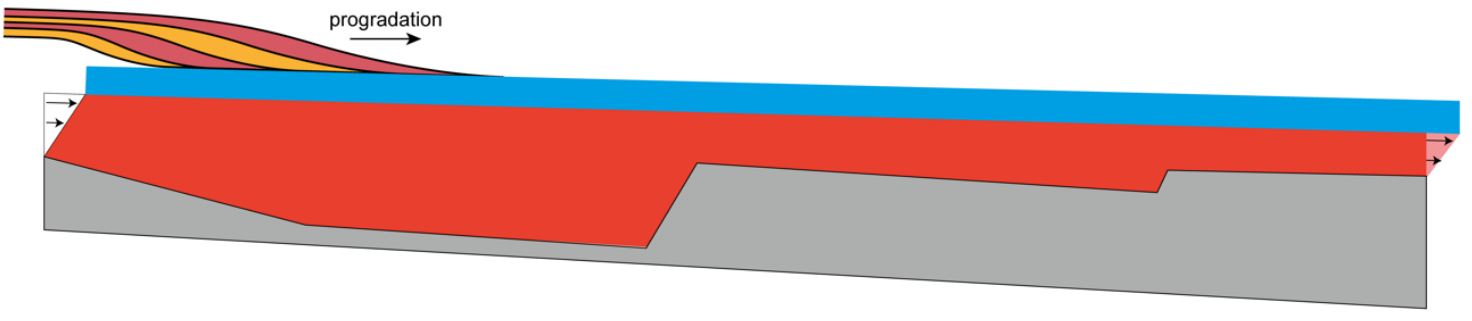

605

606 Figure 2: (a) Synthetic diagram of previous modelling scenarios (Dooley et al., 2016; 2018) investigating 607 the effects of base-salt topography on salt flow associated with basinward tilting, gravity gliding and 608 symmetric base-salt structures. (b) Synthetic diagram illustrating our modelling scenario where we test 609 the interplay of gliding and spreading over asymmetric base-salt structures characterized by half610 grabens and landward-dipping normal faults as observed in the Santos Basin. 


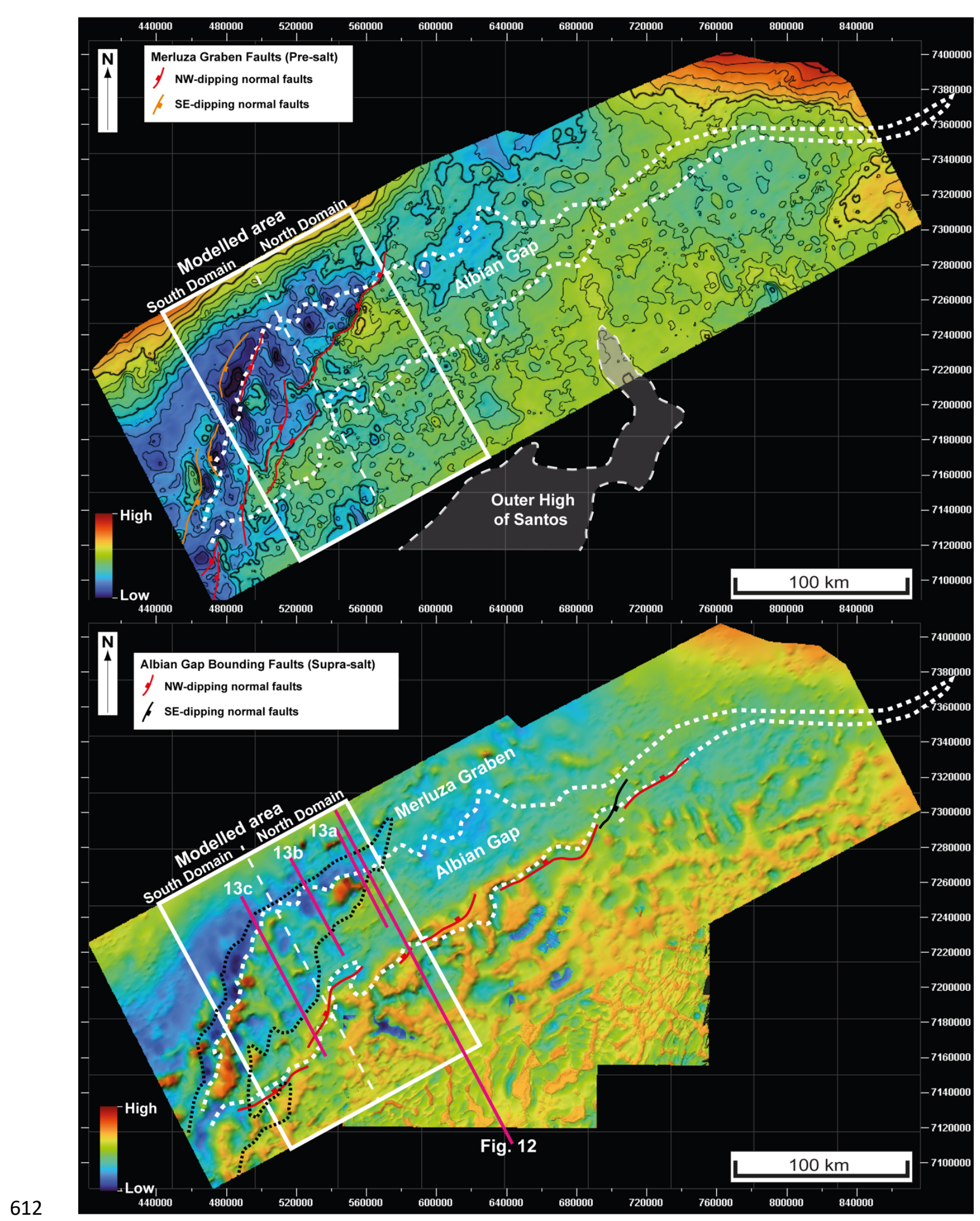

613 Figure 3: (a) Base-salt and (b) top-salt maps showing the outline of the Merluza Graben, a major and

614 complex NNE-NE-oriented base-salt structural low, and the overlying Albian Gap, a $450 \mathrm{~km}$ wide and

$615 \quad 30-65 \mathrm{~km}$ wide structure characterized by a structurally lower top-salt and is bounded basinward by 
(a) Step 1: sub-salt topography

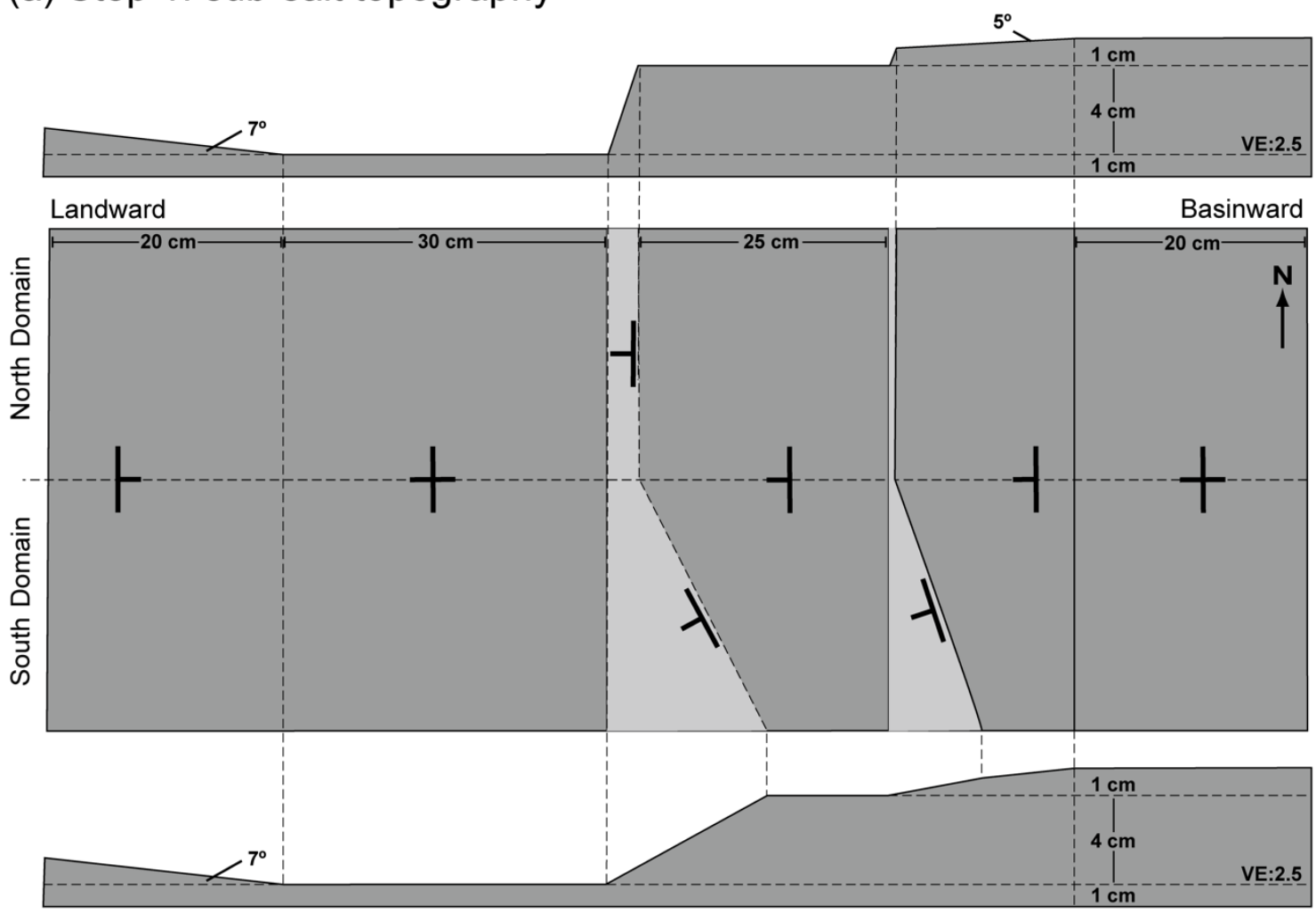

(b) Step 2: Tilting $4^{\circ}$ basinwards + salt deposition + pre-kinematic sand

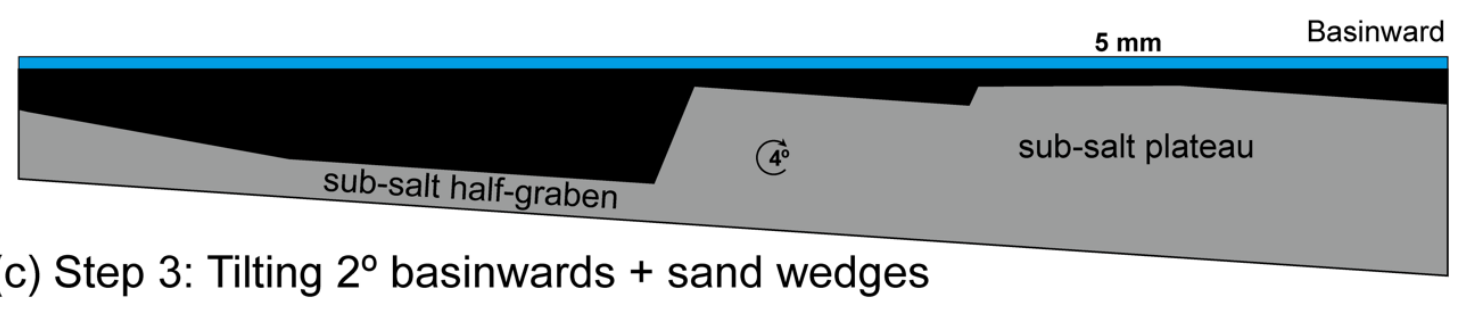
$11 \mathrm{~mm}$

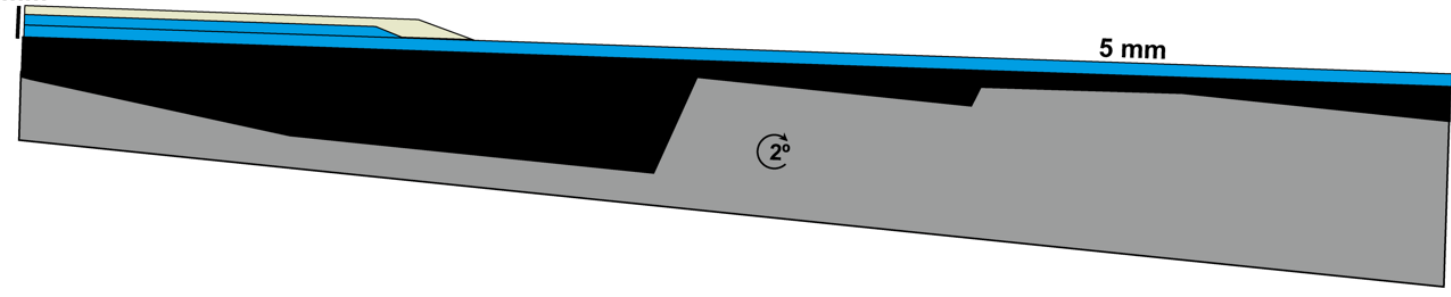

621 Figure 4: Synthetic diagram illustrating the pre-salt model setup in (a) map-view and cross-section with two different base-salt domains, the north and south domains where base-salt topography is 

illustrating the initial salt thickness variability across base-salt structures and pre-kinematic postof the model and differential loading by sand wedges.
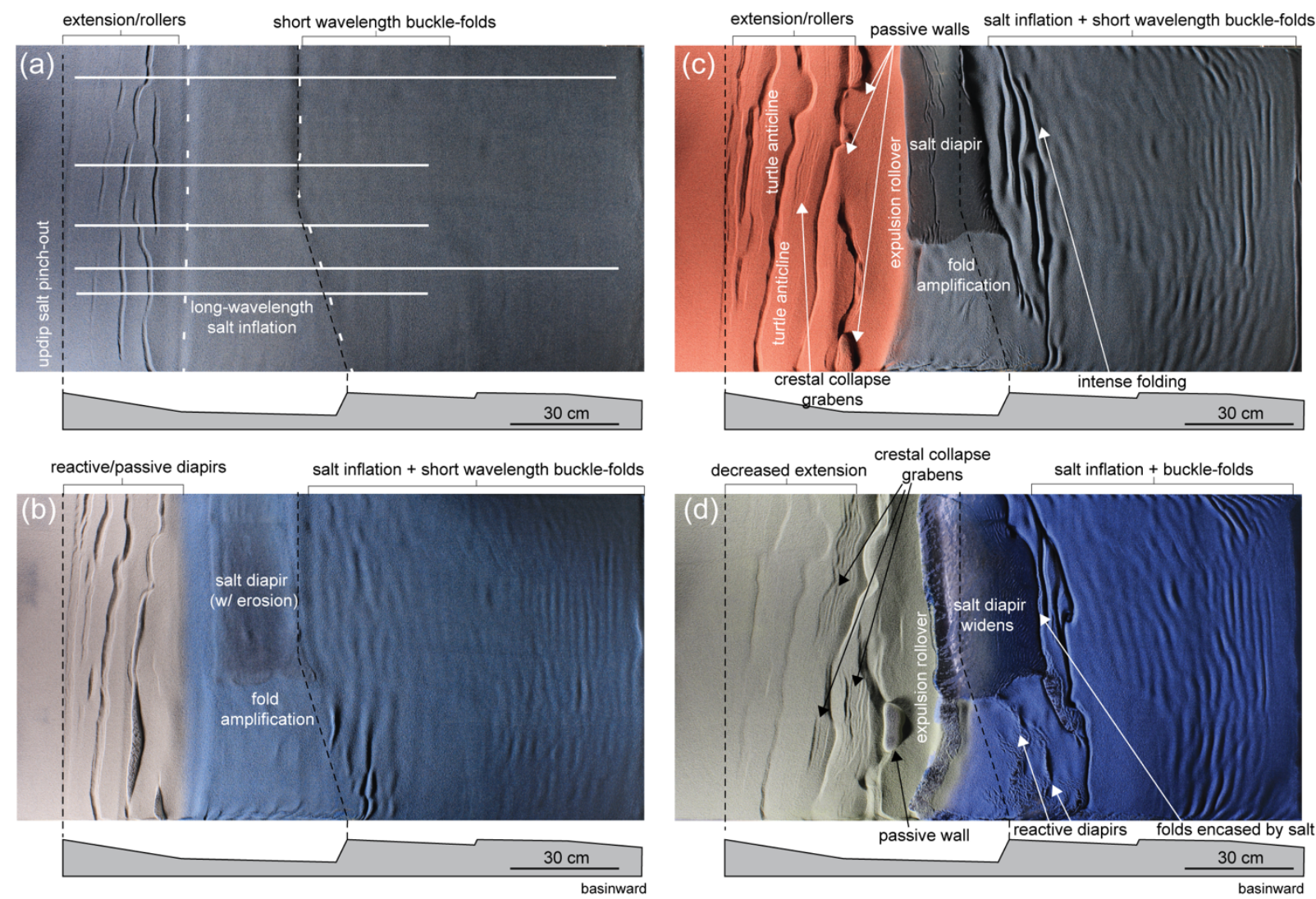

Figure 5: From (a-d), map-view snapshots of the early stages of the physical experiments when post-salt sediments prograde up to the largest landward-dipping sub-salt fault, equivalent to the Merluza Fault. Deformation is focused within the associated graben, i.e., the Merluza Graben and is characterized by updip extension, and downdip salt inflation against the Merluza Fault whilst further downdip there is salt-cored buckle folding. Early-stage erosion is simulated by removing the sediments above largest diapir formed above the graben, which allows the diapir to reach the surface and advance and widen beyond the graben onto the adjacent base-salt plateau. White lines in (d) indicate the cross-sections shown in figures 7-9. 

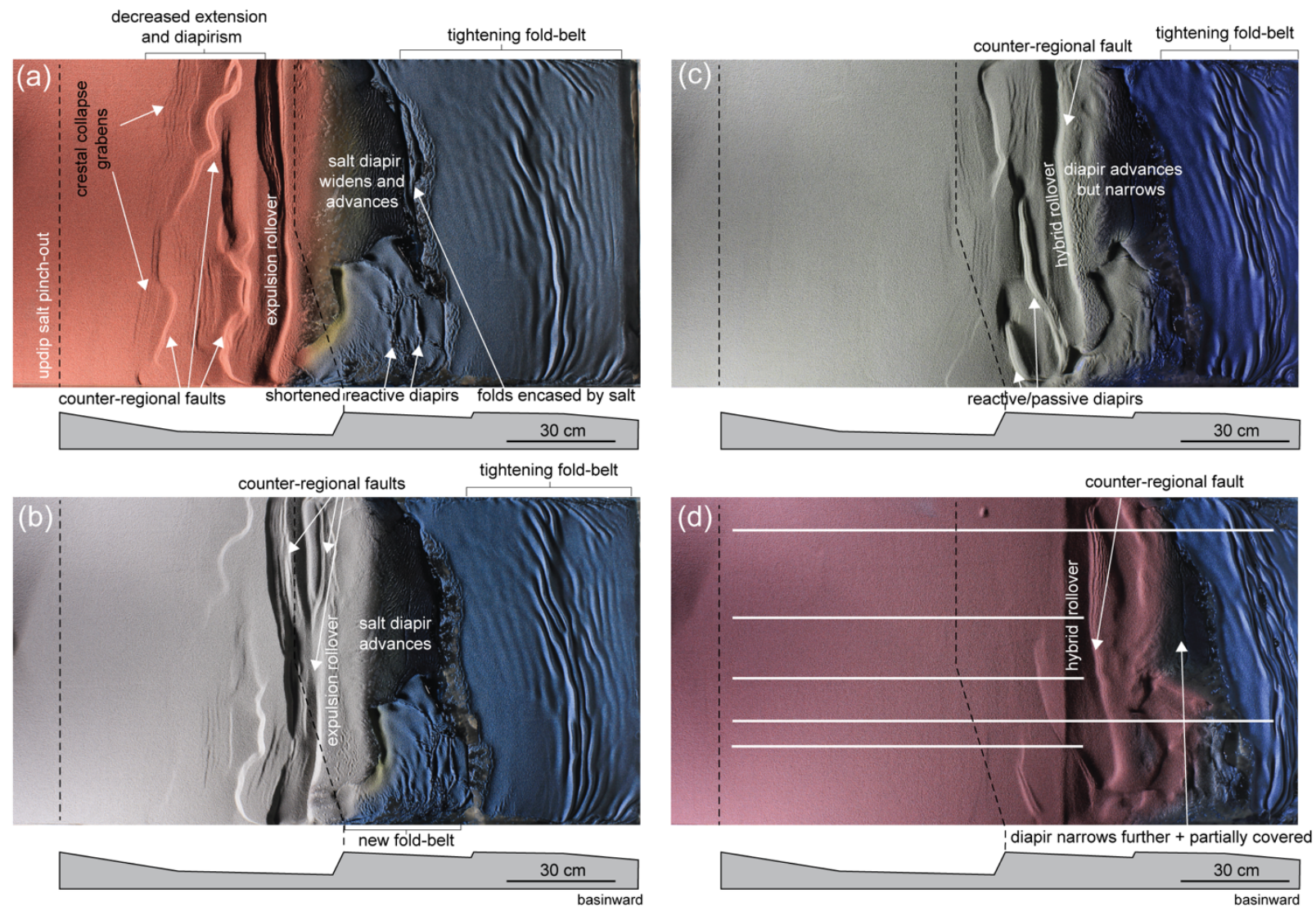

637

Figure 6: From (a-d), map-view snapshots of the late stages of the physical experiments when

639 post-salt sediments prograde beyond the largest sub-salt half-graben, the Merluza Graben

640 and onto the downdip sub-salt plateau. Deformation progresses and advances gradually

641 basinward onto the sub-salt plateau as post-salt sediments prograde. The diapir formed

previously advances further basinward, moving completely over the sub-salt plateau whilst

extension and load-driven rollovers and turtle structures form updip against the Merluza Fault.

644 The area of previously inflated salt moves laterally and extends, forming reactive diapirs in the

south as it moves beyond the Merluza Fault. White lines in (d) indicate the cross-sections

646 shown in figures 7-9. 

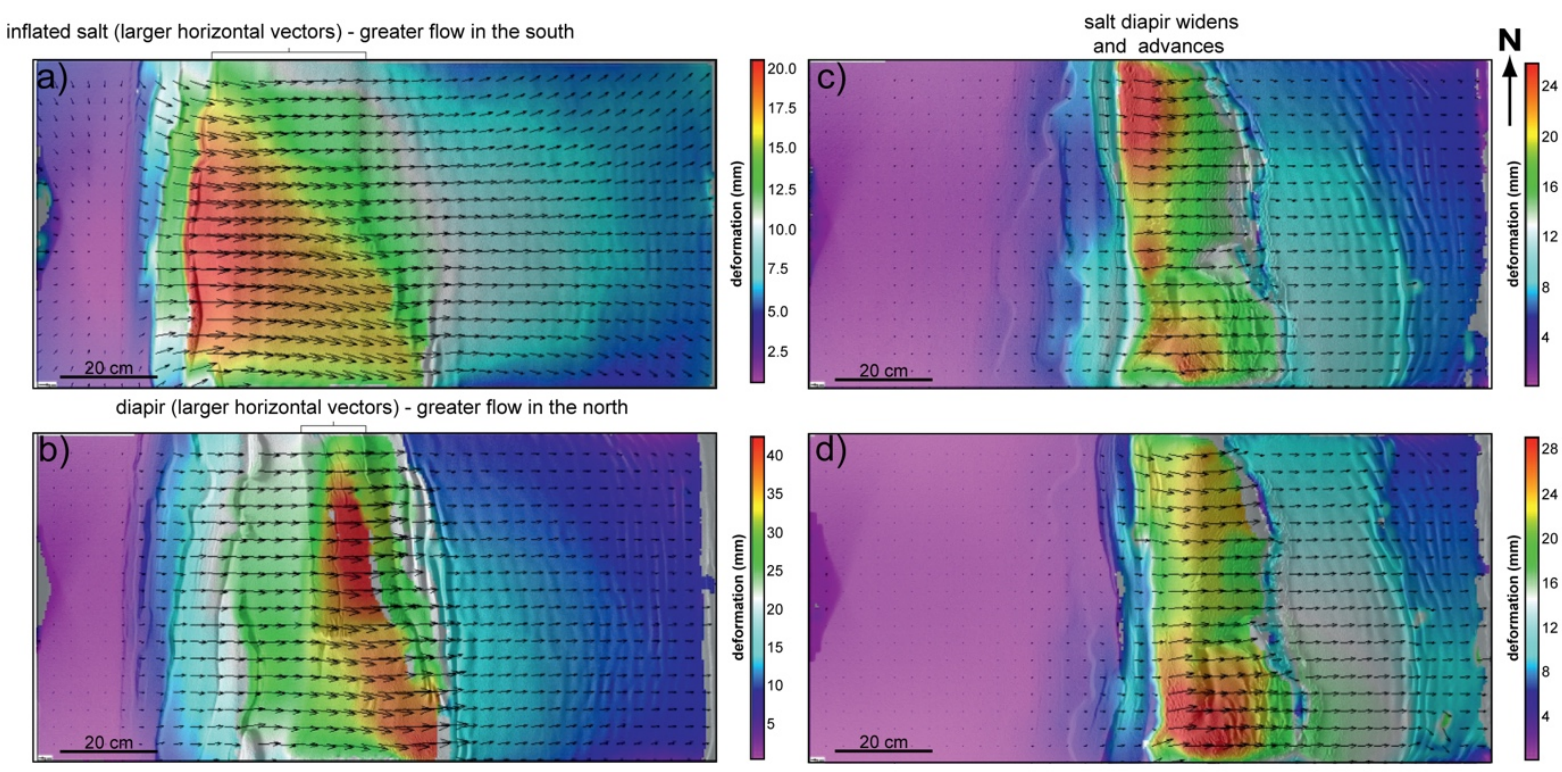

647

648 Figure 7: 2D DIC overhead imagery showing deformation at key time-steps throughout model evolution. Colours indicate the magnitude $(\mathrm{mm})$ of horizontal deformation and the arrows are vectors showing the magnitude and direction of particles movement for a specific progradational wedge. (a-b) Early stages of model evolution when progradation and deformation are concentrated updip and within the Merluza Graben being characterized by updip extension and significant salt inflation against its bounding fault. Note diapir breakthrough at the northern part of the model where both the sub-salt Merluza Graben and the zone of salt inflation are narrower. (c) Intermediate stage when progradation reaches the Merluza Fault and the previous inflated salt and large diapir translate beyond it, above the base-salt plateau. (d) Late stage when progradation reaches the sub-salt plateau and the bulk of deformation migrates beyond the Merluza Graben, being focused over the previously inflated salt. Note divergence of vectors in the centre and southern portion of the model where the sub-salt structure is oblique to direction of tectonic transport. Note also larger vectors demonstrating greater magnitude of lateral movement where the inflated salt reaches the surface and form diapirs. 


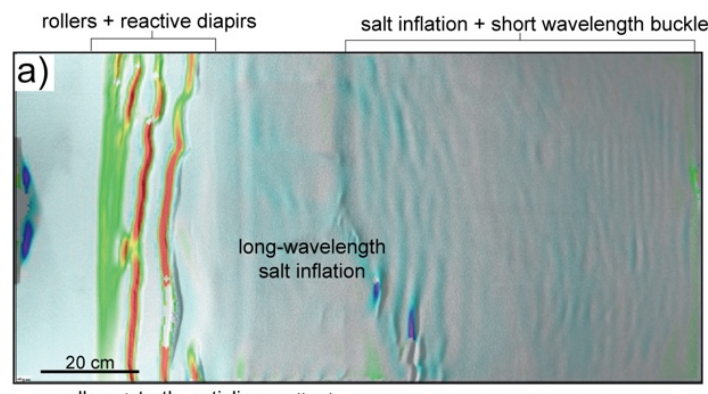

rollers + turtle anticlines diapir intense folding (tightening)

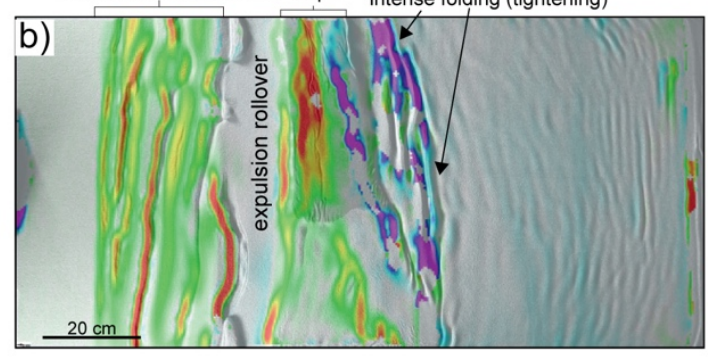

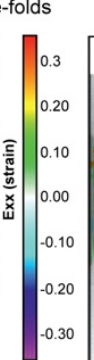
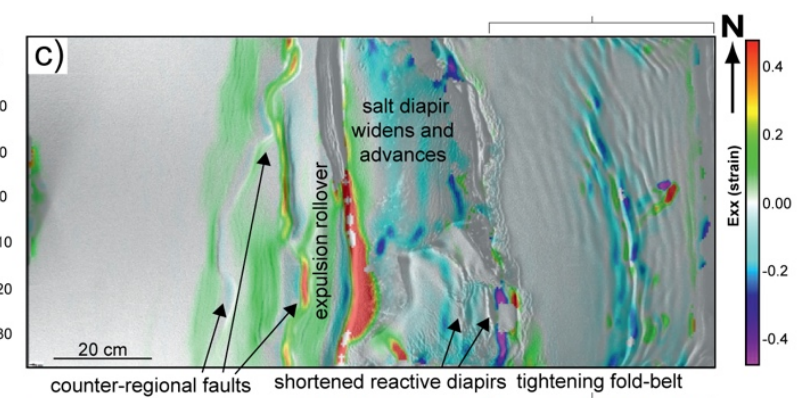

counter-regional faults shortened reactive diapirs tightening fold-belt

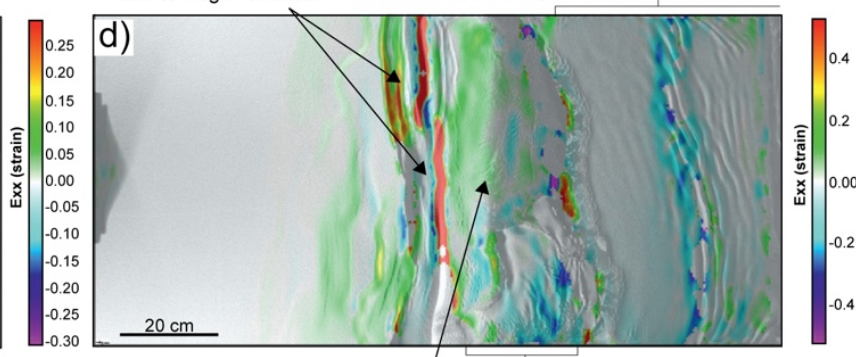

salt diapir advances \& extend new fold-belt
662

Figure 8: DIC overhead imagery showing horizontal strain: positive values (warmer colours) denote extension and negative values (cold colours) indicate shortening throughout model evolution, at the same time-steps of figure 7. (a) Initial stage showing that the bulk of deformation is focused in the updip portion of the model in the form of linear extensional structures updip of the Merluza Graben and inflated salt and salt-cored folds above and adjacent to the Merluza Graben. (b) Early stage when a wide salt diapir forms above the northern portion of the Merluza Graben and accommodates most of the deformation and salt inflation within the area. This diapir and the laterally-equivalent inflated salt in the south are affected by outer-arc extension above their crest, which is located updip of the Merluza Fault whilst being shortened and developing folds at its downdip portion above and adjacent to the Merluza Fault. Intermediate stage, (c) the diapir translates basinward above base-salt relief whilst being shortened at the toe-of-slope as it becomes covered by sediments whilst previous extensional structures located in the south are squeezed. At late stages (d), extension migrates basinward, being concentrated at the downdip portion of the Merluza Graben. The large diapir formed above the Merluza Graben widens and extends underneath the upper-slope as most of its salt is able to translated basinward beyond the Merluza Fault. Shortening occurs to the south of the diapir in the form of squeezing of smaller, previously extensional diapirs, and basinward by buckle-folding against the downdip base-salt step. 
(a)

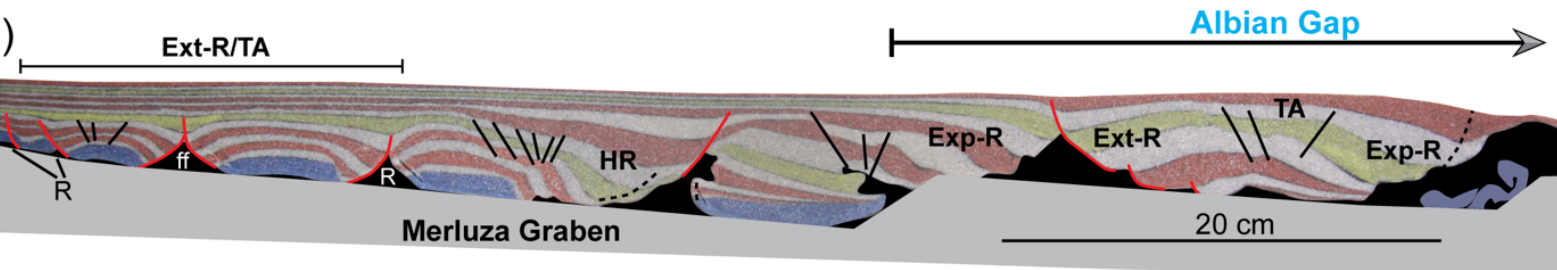

(b)

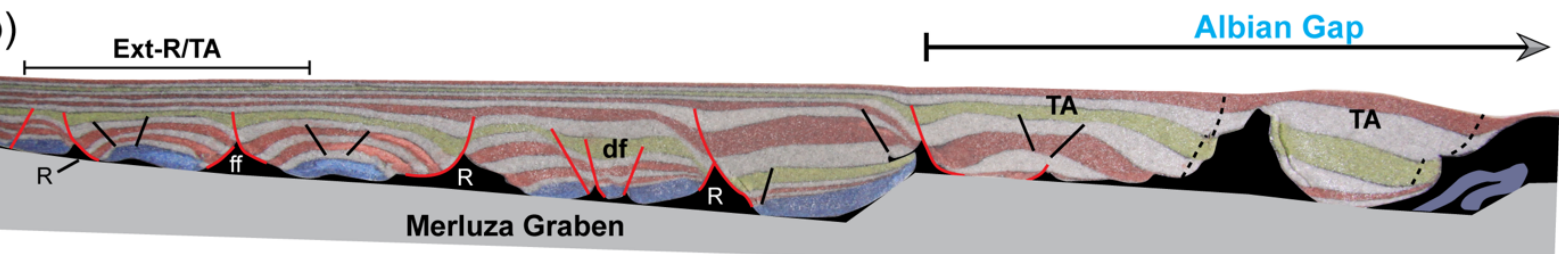

Figure 9: Physical model detailed sections from the North domain. Deformation is characterized by updip salt rollers (R), flip-flop structures (ff) and extensional turtle anticlines updip passing downdip to extensional and/or hybrid rollovers and more complex diapirs near the Merluza Fault. Further downdip, above a sub-salt plateau, deformation is characterized by more complex structures such as salt rollers, variable, i.e., extensional (Ext-R) and expulsion (Exp-R) rollovers, turtle-anticlines (TA) and tall diapirs

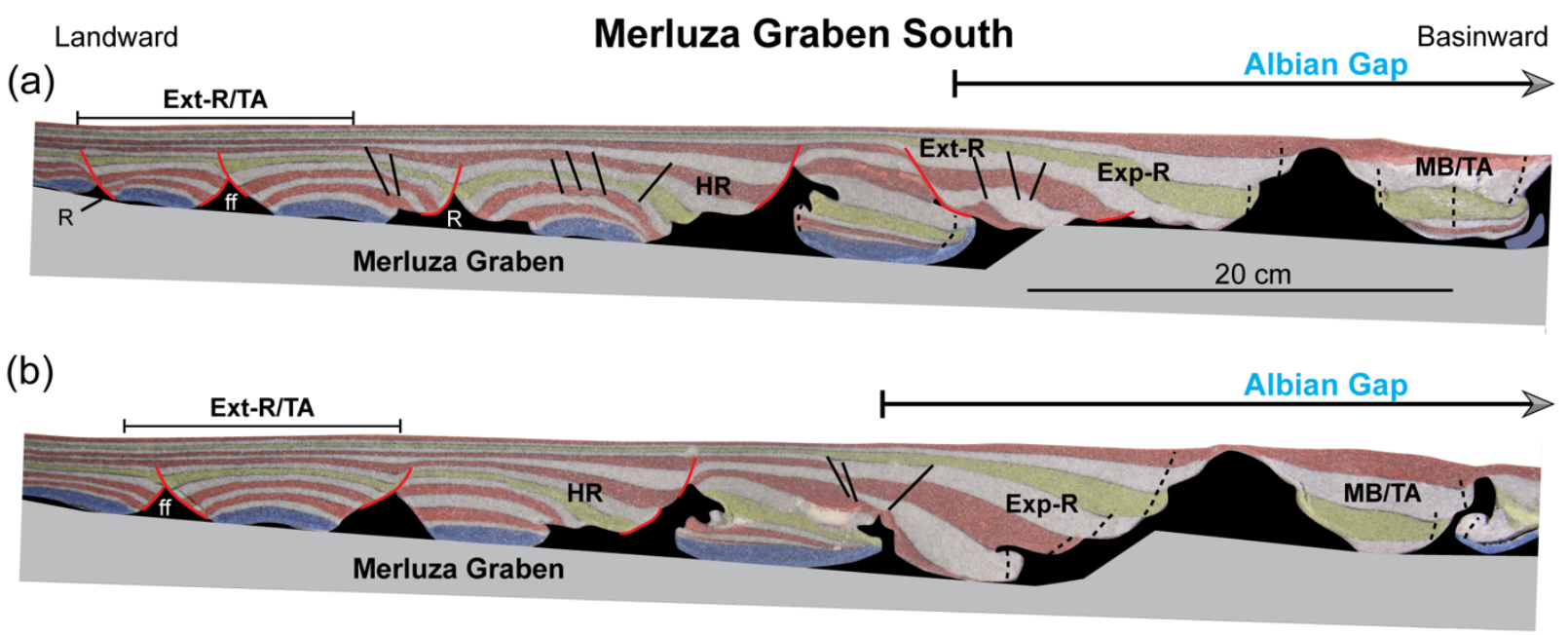

Figure 10: Physical model detailed sections from the South domain. Similar to the north domain, updip deformation is characterized by flip-flop (ff) salt rollers and turtle anticlines updip passing downdip to extensional and/or hybrid rollovers and more complex diapirs near the Merluza Fault. A large basinward-dipping rollover occurs near and above the Merluza Fault where the blue post-salt section is 
Landward

Regional Model Profiles

Basinward

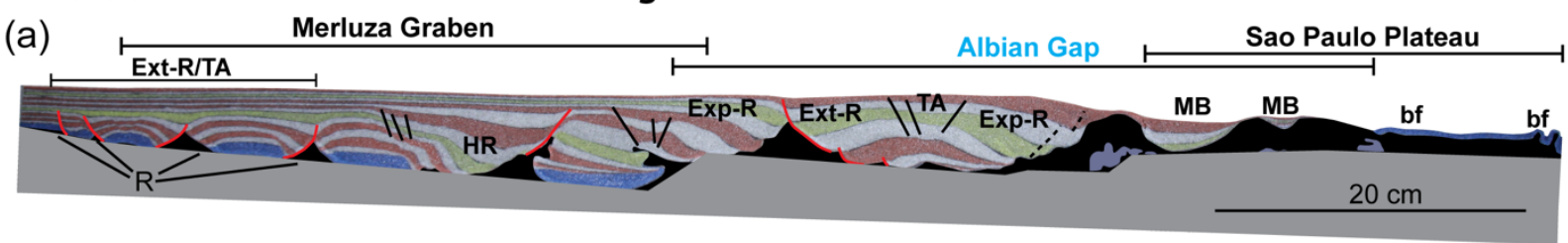

(b)

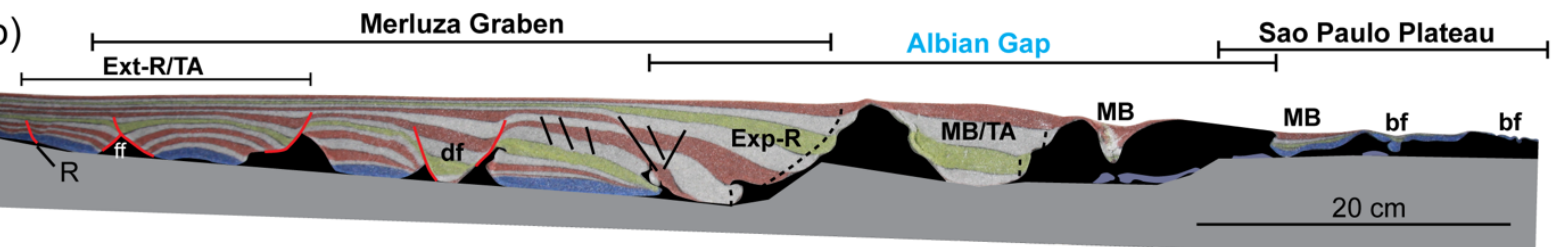

696

Figure 11: Regional model sections from (a) North Domain, and (b) South Domain illustrating the main salt-related structural styles of both domains and their relationship with the updip Merluza Graben, the Albian Gap, where the first post-salt interval is absent, and the inflated salt and associated fold-belt formed in the downdip end of the model, over the Sao Paulo Plateau.

701

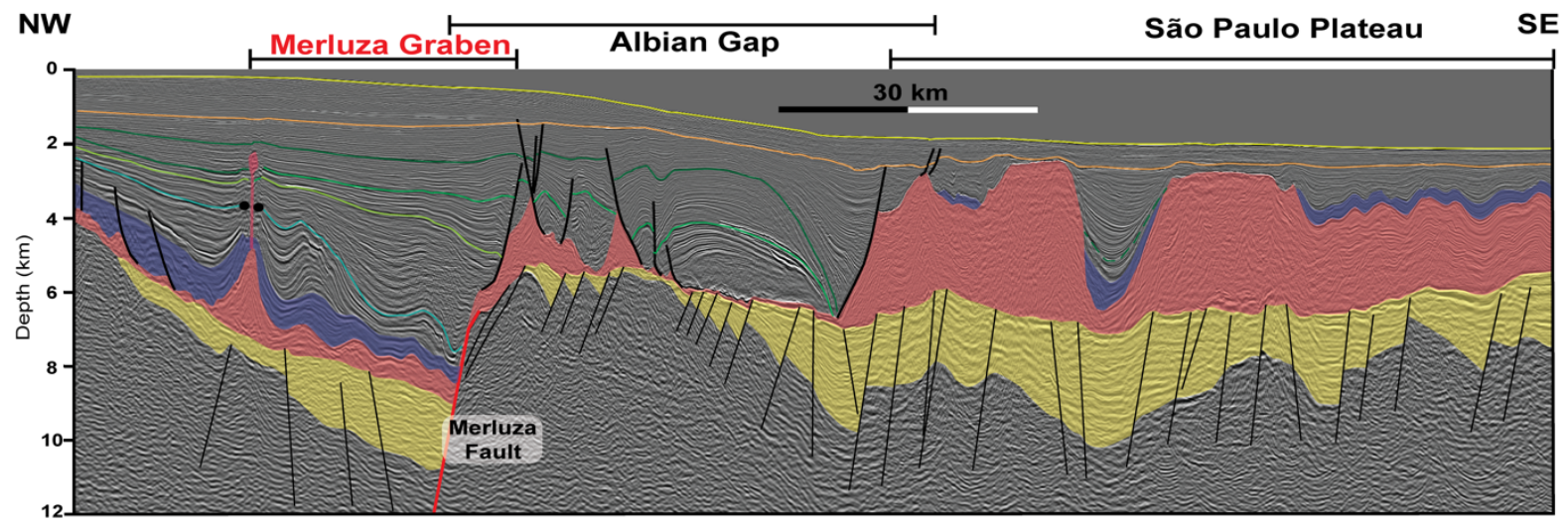

Figure 12: Regional seismic profile from the southern Santos Basin illustrating its main rift and saltrelated architecture and structural provinces, the sub-salt Merluza Graben, which passes downdip and partially overlaps laterally with the supra-salt Albian Gap and the inflated salt diapirs and salt-cored folds in the Sao Paulo Plateau. Base-, top-salt and supra-salt structures are markedly similar to regional model cross-sections shown in figure 9. 
(a)

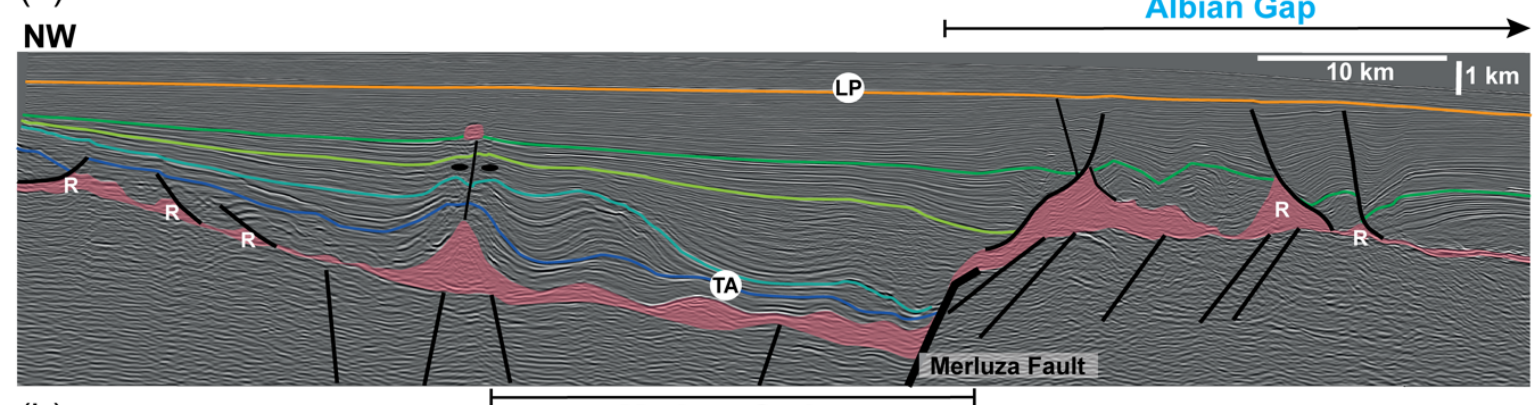

(b)
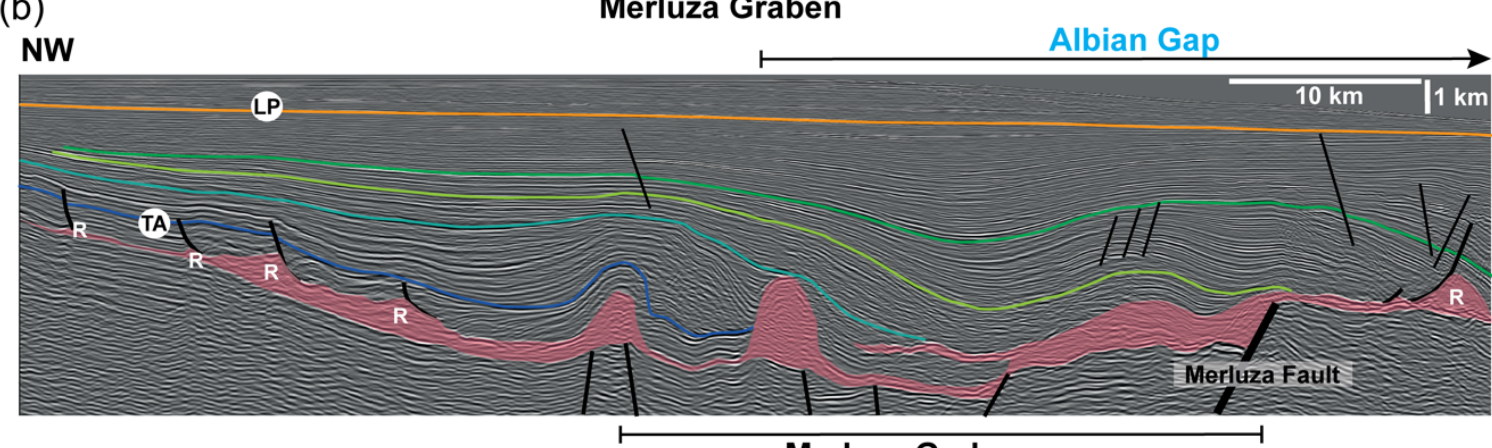

(c)

NW

Albian Gap

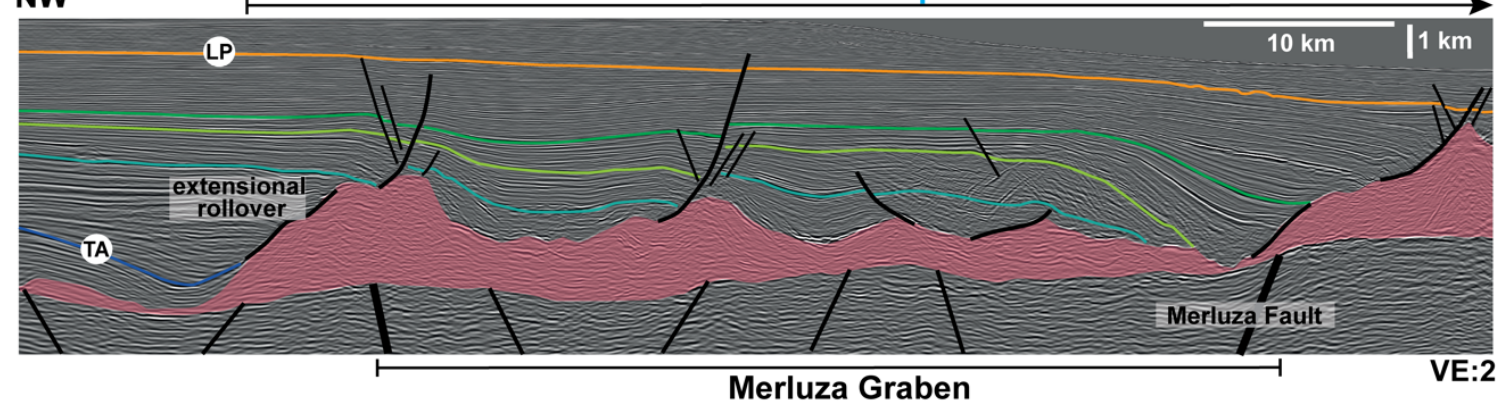

707

Merluza Graben

Figure 13: Seismic profiles from the (a-b) North domain and (c) South Domain of the study-area in the southern Santos basin, showing similar styles, spatial and temporal distribution of salt and supra-salt structures and their relationship to base-salt topography associated with the Merluza Graben and the Merluza Fault. In (a), salt rollers and extensional rollovers pass downdip to a squeezed diapir over the Merluza Graben, an`extensional basinward-dipping supra-salt rollover above the Merluza Fault and large salt rollers with landward-dipping extensional rollovers at its footwall crest. In (b), there are similar styles of structures with the main difference being above the Merluza Fault, whereas instead of an extensional rollover there is an inflated salt structure with a landward-verging salt-wing over the Merluza Fault and overlain by an expulsion-dominated rollover. In (c), where the Merluza Graben is oblique and wider, deformation is characterized by inflated salt directly overlain by post-Albian rollover strata and normal faults showing extensional reactivation of previously inflated salt. 
(a) Pure gliding

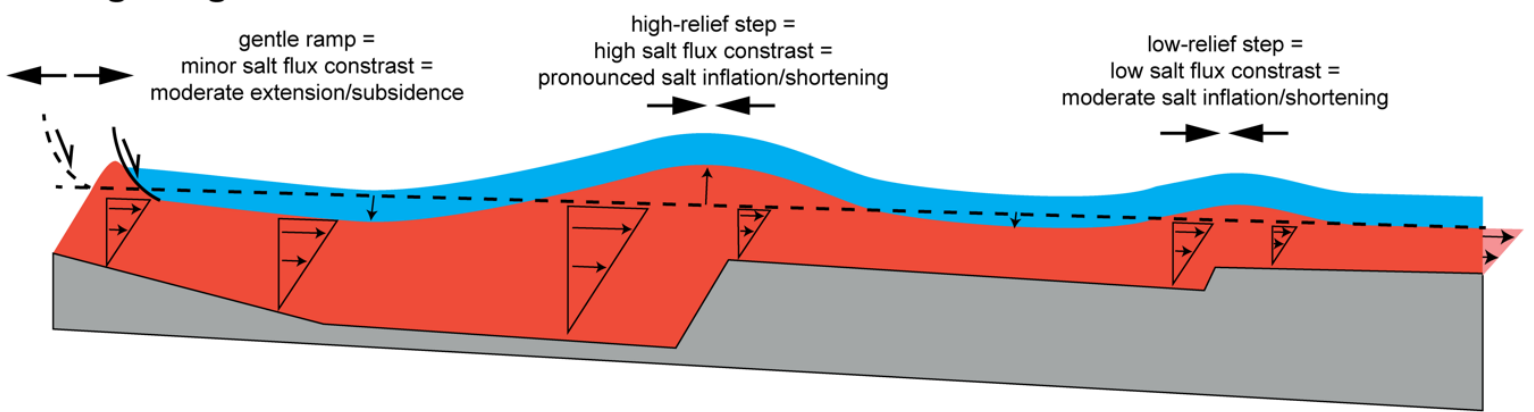

(b) Gliding + Spreading

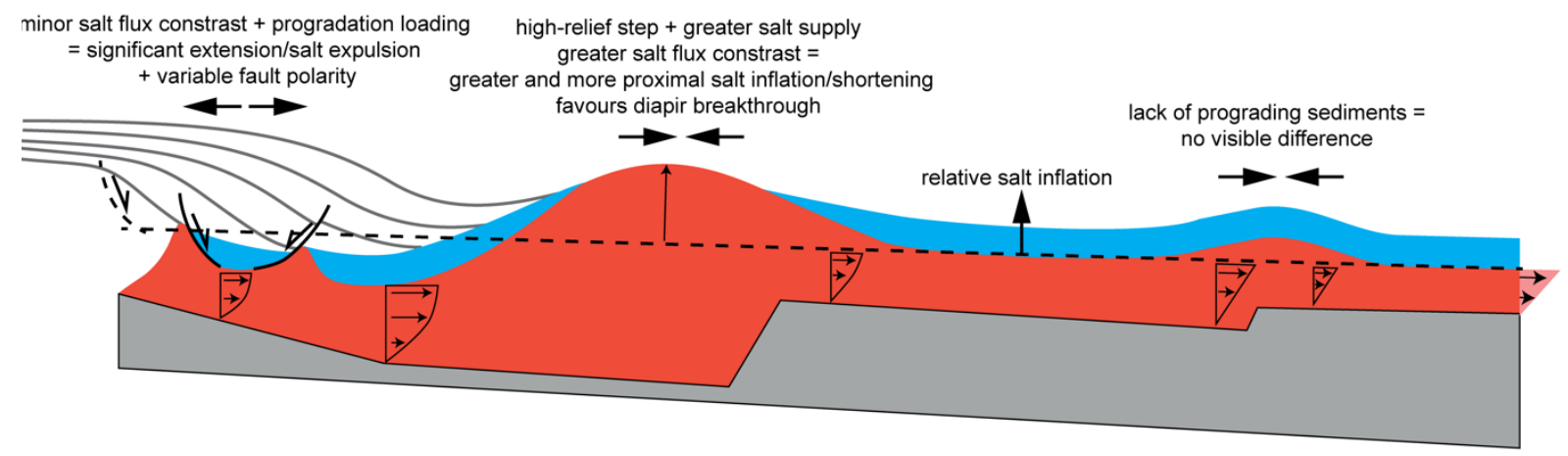

(c) Gliding + Spreading (continuation)

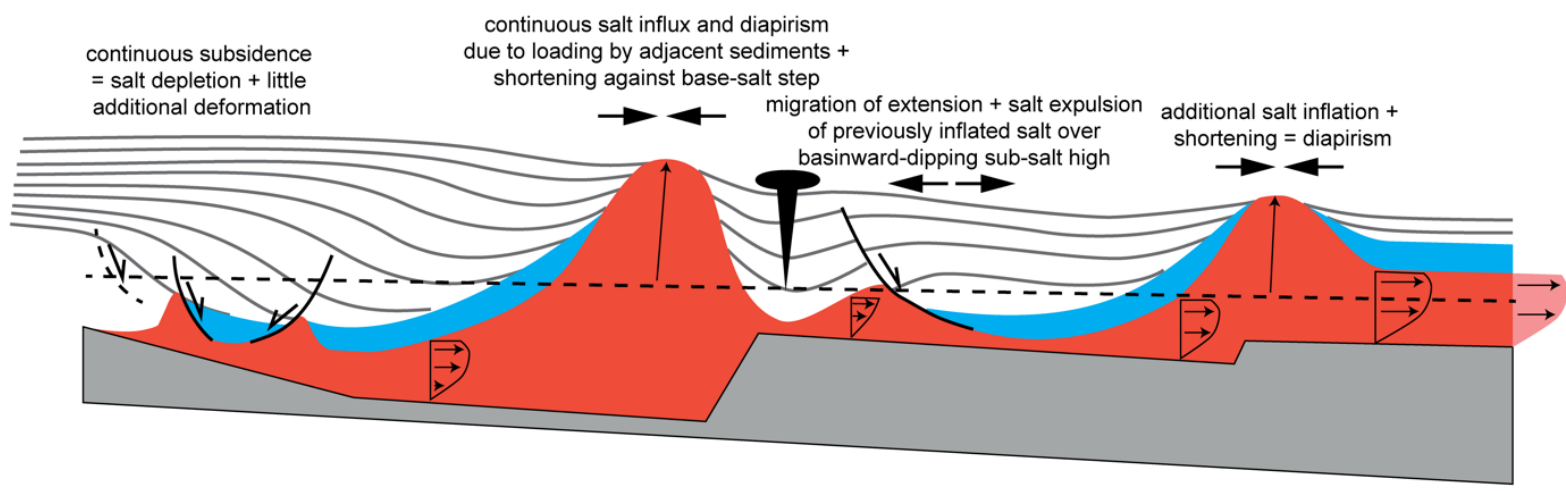

Figure 14: (a) Synthetic Diagram illustrating the effects of gliding over asymmetric base-salt relief based on experiments from Dooley et al (2016; 2018). In (b) and (c), synthetic diagrams showing the interplay between gliding and spreading associated with prograding sedimentary wedges over the same basesalt relief as simulated in our models and observed in the southern Santos Basin. In the initial stages, where prograding sediments are focused within the most proximal graben there is updip extension in the form of salt rollers and extensional rollovers above the basinward-dipping hangingwall and significant salt inflation and diapirism against its fault. This is similar to the simpler gliding scenario shown in (a), although the degree of updip extension and salt evacuation, as well as of basinward salt inflation is amplified by the differential sedimentary loading and result in larger and likely more diapiric salt structures. With continued progradation (c), sediments reach the downdip sub-salt high and the 
area that was previously located ahead of the progradation front and characterized by salt inflation. This results in salt evacuation and extension of previously inflated salt over sub-salt high and additional inflation further downdip.

\section{References}

Adam, J., \& Krézsek, C. (2012). Basin-scale salt tectonic processes of the Laurentian Basin, Eastern Canada: insights from integrated regional 2D seismic interpretation and 4D physical experiments. Geological Society, London, Special Publications, 363(1), 331-360.

Adam, J., J. Urai, B. Wieneke, O. Oncken, K. Pfeiffer, N. Kukowski, J. Lohrmann, S. Hoth, W. van der Zee, and J. Schmatz, 2005, Shear localisation and strain distribution during tectonic faulting - New insights from granular-flow experiments and high-resolution optical image correlation techniques: Journal of Structural Geology, 27, 283-301, doi: 10.1016/j.jsg.2004.08.008.

Brun, J. P., \& Fort, X. (2011). Salt tectonics at passive margins: Geology versus models. Marine and Petroleum Geology, 28(6), 1123-1145.

Cobbold, P. R., Szatmari, P., Demercian, L. S., Coelho, D., Rossello, E. A. (1995). Seismic and experimental evidence for thin-skinned horizontal shortening by convergent radial gliding on evaporites, deep-water Santos Basin, Brazil, in: Jackson, M. P. A., Roberts, D. G., Snelson, S. (eds) Salt tectonics: a global perspective. AAPG Memoir 65, 305-321.

Davison, I., Anderson, L., Nuttall, P. (2012). Salt deposition, loading and gravity drainage in the Campos and Santos salt basins. Geological Society of London Special Publications, 363(1), 159-174.

Demercian, S., Szatmari, P., Cobbold, P. R. (1993). Style and pattern of salt diapirs due to thin-skinned gravitational gliding, Campos and Santos basins, offshore Brazil. Tectonophysics, 228(3-4), 393-433. 
754 Dell'Ertole, D., and W. P. Schellart, 2013, The development of sheath folds in viscously 755 stratified materials in simple shear conditions: An analogue approach: Journal of Structural 756 Geology, 56, 129-141, doi: 10.1016/j.jsg .2013.09.002

757 Dooley, T. P., Hudec, M. R., Carruthers, D., Jackson, M. P., Luo, G. (2016). The effects of 758 base-salt relief on salt flow and suprasalt deformation patterns-Part 1: Flow across simple steps in the base of salt. Interpretation, 5(1), SD1-SD23.

760

761

762

763

764

765

766

767

Dooley, T. P., Hudec, M. R., Pichel, L. M., Jackson, M. P. (2018). The impact of base-salt relief on salt flow and suprasalt deformation patterns at the autochthonous, paraautochthonous and allochthonous level: insights from physical models. Geological Society, London, Special Publications, 476, SP476-13.

Fernandez, N., Duffy, O. B., Hudec, M. R., Jackson, M. P., Burg, G., Jackson, C. A. L., \& Dooley, T. P. (2017). The origin of salt-encased sediment packages: observations from the SE Precaspian Basin (Kazakhstan). Journal of Structural Geology, 97, 237-256.

Ferrer, O., Gratacos, O., Roca, E., Munoz, J.A., 2017. Modeling the interaction between presalt seamounts and gravitational failure in salt-bearing passive margins: the Messinian case in the northwestern Mediterranean Basin. Interpretation 5, 99-117.

Fiduk, J. C., \& Rowan, M. G. (2012). Analysis of folding and deformation within layered evaporites in Blocks BM-S-8 \&-9, Santos Basin, Brazil. Geological Society, London, Special Publications, 363(1), 471-487.

Garcia, S. F., Letouzey, J., Rudkiewicz, J. L., Danderfer Filho, A., \& de Lamotte, D. F. (2012). Structural modeling based on sequential restoration of gravitational salt deformation in the Santos Basin (Brazil). Marine and Petroleum Geology, 35(1), 337-353.

Ge, H., Jackson, M. P., \& Vendeville, B. C. (1997). Kinematics and dynamics of salt tectonics driven by progradation. AAPG bulletin, 81(3), 398-423. 
778 Gemmer, L., Ings, S. J., Medvedev, S., \& Beaumont, C. (2004). Salt tectonics driven by 779 differential sediment loading: Stability analysis and finite-element experiments. Basin 780 Research, 16(2), 199-218.

781 Gemmer, L., Beaumont, C., \& Ings, S. J. (2005). Dynamic modelling of passive margin salt 782 tectonics: effects of water loading, sediment properties and sedimentation patterns. Basin 783 Research, 17(3), 383-402.

784

785

786

787

788

789

790

791

792

793

794

795

796

797

798

799

800

Giles, K. A., \& Rowan, M. G. (2012). Concepts in halokinetic-sequence deformation and stratigraphy. Geological Society, London, Special Publications, 363(1), 7-31.

Guerra, M. C., Underhill, J. R. (2012). Role of halokinesis in controlling structural styles and sediment dispersal in the Santos Basin, offshore Brazil. Geological Society, London, Special Publications, 363(1), 175-206.

Gomes, P. O., Kilsdonk, B., Minken, J., Grow, T., \& Barragan, R. (2009). The outer high of the Santos Basin, Southern São Paulo Plateau, Brazil: pre-salt exploration outbreak, paleogeographic setting, and evolution of the syn-rift structures. In AAPG International Conference and Exhibition (pp. 15-18).

Heine, C., Zoethout, J., \& Müller, R. D. (2013). Kinematics of the South Atlantic rift. Solid Earth, 4(2), 215-253.

Hubbert, M.K., 1951. Mechanical basis for certain familiar geologic structures. Geol. Soc. Am. Bull. 62 (2), 355.

Horsfield, W.T., 1977. An experimental approach to basement-controlled faulting. Geol. Mijnb. $56,363-370$.

Jackson, M.P., Hudec, M.R. (2017). Salt Tectonics: Principles and Practice. Cambridge University Press. 
801 Jackson, C. A. L., Rodriguez, C. R., Rotevatn, A., \& Bell, R. E. (2014). Geological and 802 geophysical expression of a primary salt weld: An example from the Santos Basin, 803 Brazil. Interpretation, 2(4), SM77-SM89.

804 Jackson, C. A. L., Jackson, M. P., Hudec, M. R. (2015a). Understanding the kinematics of 805 salt-bearing passive margins: A critical test of competing hypotheses for the origin of the 806 Albian Gap, Santos Basin, offshore Brazil. Geological Society of America Bulletin, 127(11-12), $807 \quad 1730-1751$.

808 Jackson, C. A. L., Jackson, M. P., Hudec, M. R., Rodriguez, C. R. (2015b). Enigmatic 809 structures within salt walls of the Santos Basin-Part 1: Geometry and kinematics from 3D 810 seismic reflection and well data. Journal of Structural Geology, 75, 135-162.

811 Karner, G. D., Gambôa, L. A. P. (2007). Timing and origin of the South Atlantic pre-salt sag 812 basins and their capping evaporites. Geological Society, London, Special Publications, 285(1), $813 \quad 15-35$.

Krézsek, C., Adam, J. and Grujic, D (2007). Mechanics of fault and expulsion rollover systems 815 developed on passive margins detached on salt: insights from analogue modelling and optical 816 strain monitoring. Geological Society, London, Special Publications, 292(1), pp.103-121.

817 Kukla, P. A., Strozyk, F., \& Mohriak, W. U. (2018). South Atlantic salt basins-witnesses of 818 complex passive margin evolution. Gondwana Research, 53, 41-57.

Lebit, H., Arasanipalai S., Tilton, J. \& Ollagnon, P. (2019) Santos Vision: Innovative Seismic 820 Data Processing in a Super Giant Oil Basin. GeoExPro, May, 2019.

821 Lentini, M. R., Fraser, S. I., Sumner, H. S., \& Davies, R. J. (2010). Geodynamics of the central 822 South Atlantic conjugate margins: implications for hydrocarbon potential. Petroleum 823 Geoscience, 16(3), 217-229. 
Lewis, M. M., Jackson, C. A. L., \& Gawthorpe, R. L. (2013). Salt-influenced normal fault growth and forced folding: the Stavanger Fault System, North Sea. Journal of Structural Geology, 54, 156-173.

Magee, C., Pichel, L. M., Madden-Nadeau, A., Jackson, C. A. L., \& Mohriak, W. (2020). Saltmagma interactions influence intrusion distribution and salt tectonics in the Santos Basin, offshore Brazil.

Meisling, K. E., Cobbold, P. R., Mount, V. S. (2001). Segmentation of an obliquely rifted margin, Campos and Santos basins, southeastern Brazil. AAPG bulletin, 85(11), 1903-1924.

Modica, C. J., Brush, E. R., 2004. Postrift sequence stratigraphy, paleogeography, and fill history of the deep-water Santos Basin, offshore southeast Brazil. AAPG bulletin, 88(7), 923945.

Mohriak, W.U., Macedo, J.M., Castellani, R.T., Rangel, H.D., Barros, A.Z.N., Latgé, M.A.L., Mizusaki, A.M.P., Szatmari, P., Demercian, L.S., Rizzo, J.G. Aires, J.R. (1995). Salt tectonics and structural styles in the deep-water province of the Cabo Frio region, Rio de Janeiro, Brazil, in: Jackson, M. P. A., Roberts, D. G., Snelson, S. (eds) Salt tectonics: a global perspective. AAPG Memoir 65, 273-304.

Mohriak, W., Nemčok, M., Enciso, G. (2008). South Atlantic divergent margin evolution: riftborder uplift and salt tectonics in the basins of SE Brazil. Geological Society, London, Special Publications, 294(1), 365-398.

Pichel, L. M., Peel, F., Jackson, C.A.-L., Huuse, M., 2018, Geometry and kinematics of saltdetached ramp syncline basins, Journal of Structural Geology, 115, 208-230. in press, doi: 10.1016/ j.jsg.2018.07.016.

Pichel, L. M., Finch, E., \& Gawthorpe, R. L. (2019b). The Impact of Pre-Salt Rift Topography on Salt Tectonics: A Discrete-Element Modeling Approach. Tectonics, 38(4), 1466-1488. 
848 Pichel, L. M., Jackson, C. A. L., Peel, F., \& Dooley, T. P. (2019c). Base-salt relief controls salt849 tectonic structural style, São Paulo Plateau, Santos Basin, Brazil. Basin Research.

850 Pichel, L. M., \& Jackson, C. A. L. (2020b). The enigma of the Albian Gap: spatial variability 851 and the competition between salt expulsion and extension. Journal of the Geological Society.

852 Quirk, D. G., Schødt, N., Lassen, B., Ings, S. J., Hsu, D., Hirsch, K. K., Von Nicolai, C. (2012). 853 Salt tectonics on passive margins: examples from Santos, Campos and Kwanza basins. 854 Geological Society, London, Special Publications, 363(1), 207-244.

855 Rodriguez, C. R., Jackson, C. L., Rotevatn, A., Bell, R. E., Francis, M. (2019). Dual tectonic856 climatic controls on salt giant deposition in the Santos Basin, offshore Brazil. Geosphere, 857 14(1), 215-242.

858 Rowan, M. G., \& Ratliff, R. A. (2012). Cross-section restoration of salt-related deformation: 859 Best practices and potential pitfalls. Journal of Structural Geology, 41, 24-37.

860 Weijermars, R. and Schmeling, H., 1986. Scaling of Newtonian and non-Newtonian fluid 861 dynamics without inertia for quantitative modelling of rock flow due to gravity (including the 862 concept of rheological similarity). Phys. Earth Planet. Inter., 43: 316-330. 